https://doi.org/10.15407/mineraljournal.42.01.049

UDC $552.332+549(477)$

O.V. Dubyna, DrSc (Geology), Ass. prof. M.P. Semenenko Institute

of Geochemistry, Mineralogy and Ore Formation of the NAS of Ukraine

34, Acad. Palladin Ave., Kyiv, Ukraine, 03142

Taras Shevchenko National University of Kyiv, Institute of Geology

Educational-scientific institute "Institute of Geology"

90, Vasylkivska Str., Kyiv, Ukraine, 03022

E-mail: dubyna_a@ukr.net

http:/ / orcid.org/0000-0002-6003-4873

S.G. Kryvdik, DrSc (Geology \& Mineralogy), Prof., Head of Department

M.P. Semenenko Institute of Geochemistry, Mineralogy and Ore Formation of the NAS of Ukraine

34, Acad. Palladin Ave., Kyiv, Ukraine, 03142

E-mail: kryvdik@ukr.net

http:/ / orcid.org/0000-0002-8356-1115

O.A. Vyshnevskyi, PhD (Geology \& Mineralogy),

Senior Research Fellow, Leading Researcher

M.P. Semenenko Institute of Geochemistry,

Mineralogy and Ore Formation of the NAS of Ukraine

34, Acad. Palladin Ave., Kyiv, Ukraine, 03142

E-mail: vyshnevskyy@i.ua

Researcher ID: I-9996-2018

\title{
MINERALOGICAL AND PETROLOGICAL PECULIARITIES OF GRORUDITES OF EASTERN AZOV AREA (UKRAINE)
}

\begin{abstract}
Alkaline granites and their hypabyssal and effusive varieties have a limited distribution on the Ukrainian Shield, unlike other Precambrian platforms and shields. Grorudite dikes in the Eastern Azov region have discrete chemical and mineral composition and are considered as analogues of alkaline granites - pantellerites (high-Ti or aegirine type) or comendites (low-Ti or amphibole type). High-Ti grorudites are highly enriched in incompatible elements (REE, Zr and Nb) in comparison to low-Ti type. As a result of high-Ti grorudite investigation, new for these rocks titanium minerals (titaniferous hematite with high MnO content, minerals of the $\mathrm{FeTiO}_{3}-\mathrm{MnTiO}_{3}-\mathrm{ZnTiO}$ series), previously unknown in these rocks $\mathrm{Ca}$-Na-amphiboles, as well as structural relationships between aegirine and alkaline amphibole were revealed. Despite of high or increased content of HFSE in grorudites, information about their accessory minerals is quite restricted. In the aegirine-bearing varieties of grorudites, such rare elements minerals: monazite-(Ce), bastnäsite-(Ce), britholite-like mineral and REE-enriched apatite, zircon, a Na-rich mineral similar to calciocatapleiite, as well as unidentified zirconium minerals and minerals of the aeschynite group were recognized. In amphibole-bearing dikes zircon and Nb-bearing rutile were only found. These minerals are often very small in size, the largest of them can reach 15-20 $\mu \mathrm{m}$ in size; mostly do not exceed $10 \mu \mathrm{m}$. It greatly complicates their identification. An interesting and unusual fact is that many of rare minerals, especially bastnäsite-(Ce), aeschynite group minerals and zircon are present as inclusions in titaniferous hematite. It is assumed that a significant part of rare metals isomorphically incorporate to rock-forming minerals (alkaline pyroxenes and amphiboles). Some of rare minerals (especially zirconium ones) are secondary mineral and were formed as a result of replacement of primary $\mathrm{Na}$ (eudialyte, catapleiite, hilairite) or Ca (gittinsite, calciocatapleiite) Zr-silicates, which are more typical in peralkaline (agpaitic) rocks. Taking into account the petrological features and the nature of the rare-earth mineralization of grorudites of the Eastern Azov region, there is a reason to believe that such type of mineralization in these rocks occurs in course of differentiation of the initial magmatic melt(s). Such melts are similar to high-Ti basalts (characteristic rocks of this region) of Devonian age. Secondary hydrothermal processes are weakly manifested
\end{abstract}

Цитування: Dubyna O.V., Kryvdik S.G., Vyshnevskyi O.A. Mineralogical and Petrological Peculiarities of Grorudites of Eastern Azov Area (Ukraine). Мінерал. жсурн. 2020. 42, № 1. С. 49-65. https://doi.org/10.15407/mineraljournal.42.01.049 
in the studied rocks and probably led to substitution of primary accessory minerals. Considering the increased or high concentrations of $\mathrm{Nb}$ in high-Ti grorudites and an insignificant amount of $\mathrm{Nb}$-minerals, it is likely that differentiation conditions (low $F$, high $\mathrm{fO}_{2}$ and hypabyssal conditions of crystallization) did not promote prolonged crystallization with significant accumulation of rare-metal minerals. However, the presence of grorudites with high content of rare metals found in this region increases the prospects for discovery of small alkaline granite intrusions (holocrystalline analogues of grorudites) which may host deposits and/or occurrences of $\mathrm{Nb}, \mathrm{REE}, \mathrm{Zr}, \mathrm{Sn}, \mathrm{Be}$.

Keywords: grorudite, alkaline granite, aeschynite-(Ce), zirconium minerals, monazite-(Ce), bastnäsite-(Ce), britholite-like mineral, REE-apatite, $\mathrm{Na}$-rich calciocatapleiite.

Introduction. Among all igneous rocks, alkaline rocks contain the highest concentrations of $\mathrm{Zr}$ and other HFSE. The significant resources of these elements are often hosted in alkaline intrusive complexes. So, massifs of alkaline granites or alkaline rocks of syenite-granitic composition host economic or potentially economic HFSE resources in many countries, for instance, the Strange Lake granites (Canada) with rich $\mathrm{Zr}$, Y, REE, Nb mineralization [32, 33, 47], the Khaldzan-Buregtey (Mongolia) deposit in peralkaline granite with large resources of $\mathrm{Zr}, \mathrm{Nb}$ and REE [25], the Amis complex (Namibia) with $\mathrm{Zr}, \mathrm{Nb}$, and REE mineralization [41].

Despite the fact that numerous works dedicated to alkaline granites have been published, the genesis of associated HFSE mineralization is quite often controversial. Most of their HFSE deposits are thought to appear as a result of combination of magmatic and hydrothermal processes, although in some cases one of these processes can be dominant [38].

Unlike other Precambrian platforms and shields, alkaline granites and their hypabyssal or effusive varieties are not common on the Ukrainian Shield. Aegirine and riebeckite in granites are known in the Perga area (Perga granite complex), as well as grorudites in the Eastern Azov region that occur as the dike analogues of pantellerites (high-Ti or aegirine type) and comendites (low-Ti or amphibole type) $[7,12]$. Their geological position, chemical composition, mineralogical and geochemical characteristics were considered in details by $[5,7,8,12$, 14]. Grorudites are the most interesting alkaline rocks in terms of petrological and geochemical aspects and still poorly investigated. Moreover, aegirine and amphibole varieties have different strikes (northwest and sublatitude, respectively). At the same time, aegirine grorudites are usually enriched (as for alkaline granites) in titanium (0.9$\left.1.43 \% \mathrm{TiO}_{2}\right)$ and incompatible elements $(\mathrm{Zr}, \mathrm{Nb}$, LREE) (Table 1). However, own minerals of these elements have not been discovered so far, and their findings (zircon, rutile, cheralite) have been mentioned only in crushed samples [12]. Partially it is due to rather small size of accessory minerals in these rocks (hundredth, rarely tenth parts of a millimeter). It is possible that during the sample preparation such fine-grained accessory minerals, considering their high density and hardness, were crushed and subsequently lost during washing. Our investigation of aegirine and amphibole grorudites allowed to identify own rare metal minerals, as well as titanium minerals (titaniferous hematite, $\mathrm{FeTiO}_{3}-\mathrm{MnTiO}_{3}-\mathrm{ZnTiO}_{3}$ series minerals). As for $\mathrm{Nb}$ - and $\mathrm{Zr}$-bearing minerals (aeschynite group and $\mathrm{Na}$-enriched calciocatapleiite), they are not fully identified. Also, the new types of $\mathrm{Ca}-\mathrm{Na}$ amphiboles as well as previously unknown structural relationships between aegirine and alkaline amphibole have been identified.

Methods. The major element compositions of grorudites samples were determined by standard chemical analysis at the Chemical Laboratory of the M.P. Semenenko Institute of Geochemistry, Mineralogy, and Ore Formation (IGMOF), National Academy of Sciences of Ukraine. Trace and rare earth elements were determined in two samples by inductively coupled plasma-mass spectrometry $(I C P-M S)$ at Acme Analytical Laboratories (Vancouver, Canada) using an ELAN 9000 ICP$M S$; fifteen samples were analyzed by $X R F$ at the Chemical Laboratory of the IGMOF of the NAS of Ukraine.

Three samples of grorudites, two of them being high-Ti aegirine type of grorudite and one low-Ti amphibole type, have been studied by $J C X A-733$ $(J E O L)$ electron microprobe equipped with three vertical wavelength dispersive spectrometers, in the IGMOF of the NAS of Ukraine. The analytical conditions were as follows: acceleration voltage of $15 \mathrm{kV}$, beam current $20 \mathrm{nA}$, and beam diameter of $2 \mu \mathrm{m}$; counting times per analysis of $30 \mathrm{~s}$ on peak and $10 \mathrm{~s}$ on both background positions.

The chemical composition of rare metal minerals was determined using $J S M-6700 F$ field emission scanning electron microscope equipped with $J E D$ 2300 energy-dispersive spectrometer $(J E O L)$ in the IGMOF of the NAS of Ukraine. Operating conditions were as follows: $20 \mathrm{kV}$ accelerating voltage, $1.0 \mathrm{nA}$ beam current, $2 \mu \mathrm{m}$ beam size and a counting 
time of 90 seconds for one analysis. Pure metals, synthetic compounds and natural minerals were used for calibration. Raw counts were corrected for matrix effects with the ZAF algorithm implemented by JEOL.

Mafic minerals and their textural relationships. As shown by previous authors [12], the most typical mafic minerals in aegirine type grorudites are rare aegirine phenocrysts (up to $1 \mathrm{~cm}$ ), aegirine microlites in groundmass, and arfvedsoniteriebeckite amphiboles (but rare individual crystals of amphibole similar to richterite were mentioned too); in amphibole type grorudites there are phenocrysts of arfvedsonite-riebeckite am- phiboles, the groundmass hosts aegirine and $\mathrm{Na}-$ amphiboles.

Low $\mathrm{Na}_{2} \mathrm{O}(7.0-7.47 \%)$ and $\mathrm{CaO}(0.7-2.7 \%)$ content (which are more common for riebeckite) were noticed previously [7] in $\mathrm{Na}-\mathrm{Ca}$-amphiboles from amphibole type grorudites. According to the new data, amphibole composition is more diverse, as amphiboles with low (riebeckite $6.2 \% \mathrm{Na}_{2} \mathrm{O}$ and $2.7 \% \mathrm{~K}_{2} \mathrm{O}$ ) and high alkali content (arfvedsonite $\mathrm{Na}_{2} \mathrm{O}$ up to 10 and $\mathrm{K}_{2} \mathrm{O}$ up to $1.9 \%$ ) have been identified. The degree of iron oxidation in the riebeckite-arfvedsonite amphiboles is lower than that in the associated aegirine. So, in the riebeckite formula three of the five octahedral cations are

Table 1. Chemical compositions (wt \%) and concentration of some trace elements (ppm, XRF) in representative samples of grorudites of Eastern Azov region by [12]

\begin{tabular}{|c|c|c|c|c|c|c|c|c|c|c|c|}
\hline \multirow{3}{*}{ Component } & \multicolumn{5}{|c|}{ High-Ti with aegirine } & \multicolumn{6}{|c|}{ Low-Ti with amphibole } \\
\hline & 1 & 2 & 3 & 4 & 5 & 6 & 7 & 8 & 9 & 10 & 11 \\
\hline & $87-2$ & $87-2 / 1$ & $87-2 / 3$ & $88-2 / 1$ & $88-2$ & $89-8 / 1$ & $89-8 / 2$ & $89-8 / 3$ & $87-3 / 2$ & $89-9$ & $89-9 / 2$ \\
\hline $\mathrm{SiO}_{2}$ & 73.19 & 74.2 & 73.0 & 71.4 & 72.8 & 75.0 & 74.0 & 73.95 & 74.38 & 74.2 & 75.8 \\
\hline $\mathrm{TiO}_{2}$ & 1.43 & 1.43 & 1.43 & 1.04 & 1.04 & 0.34 & 0.35 & 0.36 & 0.3 & 0.33 & 0.35 \\
\hline $\mathrm{Al}_{2} \mathrm{O}_{3}$ & 7.9 & 8.1 & 7.9 & 9.2 & 8.6 & 10.4 & 10.2 & 10.0 & 10.04 & 10.4 & 10.6 \\
\hline $\mathrm{Fe}_{2} \mathrm{O}_{3}$ & 6.65 & 5.8 & 6.2 & 5.86 & 6.7 & 1.9 & 2.3 & 2.84 & 2.01 & 2.1 & 1.7 \\
\hline $\mathrm{FeO}$ & 1.36 & 1.15 & 1.22 & 2.02 & 1.3 & 3.6 & 2.88 & 2.66 & 2.87 & 2.88 & 2.66 \\
\hline $\mathrm{MnO}$ & 0.23 & 0.17 & 0.2 & 0.23 & 0.31 & 0.11 & 0.09 & 0.09 & 0.15 & 0.1 & 0.06 \\
\hline $\mathrm{MgO}$ & 0.36 & 0.34 & 0.32 & 0.26 & 0.2 & 0.02 & 0.03 & - & 0.3 & - & 0.04 \\
\hline $\mathrm{CaO}$ & 0.35 & 0.35 & 0.7 & 0.45 & 0.33 & 0.3 & 0.4 & 0.28 & 0.22 & 0.22 & 0.2 \\
\hline $\mathrm{ZrO}_{2}$ & - & - & - & 0.19 & 0.17 & 0.12 & 0.11 & 0.11 & - & 0.11 & 0.13 \\
\hline $\mathrm{Na}_{2} \mathrm{O}$ & 3.84 & 3.84 & 3.84 & 4.32 & 3.68 & 4.6 & 4.2 & 4.2 & 4.32 & 4.2 & 3.84 \\
\hline $\mathrm{K}_{2} \mathrm{O}$ & 4.5 & 4.4 & 4.5 & 4.48 & 4.32 & 3.2 & 4.46 & 4.62 & 4.86 & 4.4 & 4.32 \\
\hline $\mathrm{P}_{2} \mathrm{O}_{5}$ & 0.03 & 0.03 & 0.11 & 0.08 & 0.03 & 0.03 & 0.03 & 0.05 & 0.05 & 0.06 & 0.05 \\
\hline $\mathrm{CO}_{2}$ & 0.24 & - & - & 0.1 & 0.07 & 0.14 & 0.17 & 0.06 & 0.21 & 0.2 & 0.17 \\
\hline $\mathrm{S}\left(\mathrm{SO}_{3}\right)$ & 0.02 & 0.02 & 0.02 & - & - & 0.01 & 0.01 & 0.02 & - & 0.05 & 0.02 \\
\hline $\mathrm{H}_{2} \mathrm{O}^{-}$ & - & - & 0.1 & 0.15 & 0.4 & - & - & - & - & - & - \\
\hline LOI & 0.3 & 0.32 & 0.73 & - & 0.17 & 0.26 & 0.45 & 0.34 & 0.1 & 0.32 & 0.43 \\
\hline Total & 100.4 & 100.2 & 100.27 & 99.8 & 100.12 & 100.03 & 99.68 & 99.58 & 99.81 & 99.57 & 100.37 \\
\hline$(\mathrm{Na}+\mathrm{K}) / \mathrm{Al}$ & 1.43 & 1.37 & 1.42 & 1.3 & 1.26 & 1.06 & 1.16 & 1.19 & 1.23 & 1.13 & 1.03 \\
\hline $\mathrm{Na}_{2} \mathrm{O} / \mathrm{K}_{2} \mathrm{O}$ & 0.85 & 0.87 & 0.85 & 0.96 & 0.85 & 1.44 & 0.94 & 0.91 & 0.89 & 0.95 & 0.89 \\
\hline $\mathrm{Cr}$ & 25 & 20 & 20 & - & 20 & 22 & 5 & 5 & 10 & 10 & 5 \\
\hline $\mathrm{Ni}$ & 20 & 20 & 20 & - & 20 & 20 & 15 & 15 & 17 & 15 & 15 \\
\hline $\mathrm{Li}$ & 60 & 60 & 250 & 10 & 10 & 40 & 60 & 50 & 15 & 10 & 30 \\
\hline $\mathrm{Be}$ & 4 & 4 & 4 & 4 & 6 & 3 & 3 & 4 & 5 & 2 & 2 \\
\hline $\mathrm{Rb}$ & 175 & 180 & 205 & 175 & 175 & 90 & 162 & 165 & 144 & 144 & 165 \\
\hline $\mathrm{Ba}$ & 39 & 54 & 34 & 51 & 74 & 73 & 26 & 40 & 40 & 40 & 90 \\
\hline $\mathrm{Sr}$ & 45 & 35 & 35 & 10 & 10 & 10 & 40 & 10 & 10 & 10 & 10 \\
\hline $\mathrm{Nb}$ & 1218 & 120 & 273 & 420 & 400 & 140 & 112 & 112 & 112 & 125 & 133 \\
\hline $\mathrm{Zr}$ & 1557 & 1588 & 1445 & 1494 & 1580 & 948 & 925 & 887 & 886 & 837 & 1071 \\
\hline Th & 15 & 15 & 15 & 25 & 20 & 10 & 10 & 9 & 10 & 10 & 15 \\
\hline $\mathrm{Y}$ & 180 & 180 & 162 & 140 & 207 & 130 & 112 & 103 & 122 & 117 & 140 \\
\hline $\mathrm{La}$ & 175 & 119 & 146 & 186 & 235 & 154 & 105 & 63 & 122 & 139 & 45 \\
\hline $\mathrm{Ce}$ & 320 & 203 & 193 & 279 & 343 & 231 & 156 & 95 & 189 & 229 & 129 \\
\hline $\mathrm{Nd}$ & 238 & 166 & 155 & 204 & - & 184 & 129 & 141 & 140 & 141 & 83 \\
\hline
\end{tabular}




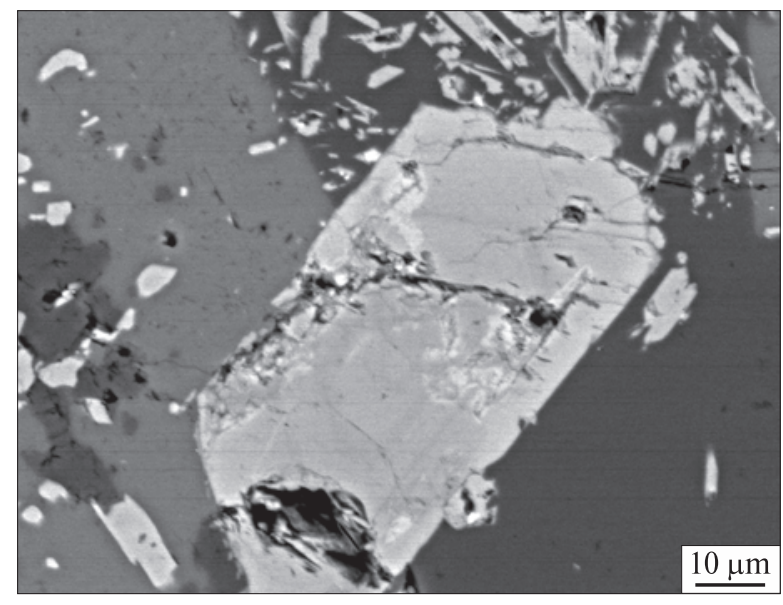

Fig. 1. Amphibole phenocryst with heterogeneous texture and irregular zonality in aegirine grorudite (BSE image). The lighter areas and the central part of the phenocryst are rich in $\mathrm{MnO}$ and $\mathrm{CaO}$

$\mathrm{Fe}^{+3}$, whereas in arfvedsonite the iron oxidation degree is lower with one $\mathrm{Fe}^{+3}$ per formula.

Some amphibole phenocrysts reveal obscure zoning with $\mathrm{MgO}$-rich (up to 8.8\%) cores, whereas separate areas have a composition similar to winchite $\left(5.87 \% \mathrm{CaO}, 3.8 \% \mathrm{Na}_{2} \mathrm{O}, 0.8 \% \mathrm{~K}_{2} \mathrm{O}\right.$, and $5.55 \% \mathrm{MnO}$, Table 2, Fig. 1). Small needle-like inclusions of amphibole and its horseshoe-like rim in and around quartz have been analyzed, too (Fig. 2). In contrast to the mentioned above phenocrysts of amphibole, they reveal maximum enrichment in $\mathrm{FeO}$ and alkalis, lack of $\mathrm{MgO}$ and insignificant $\mathrm{CaO}$ content which are typical for arfvedsonite (Table 2, an. 9). Amphibole of richterite composition $\left(5.05 \% \mathrm{CaO}, 7.27 \% \mathrm{Na}_{2} \mathrm{O}\right.$,

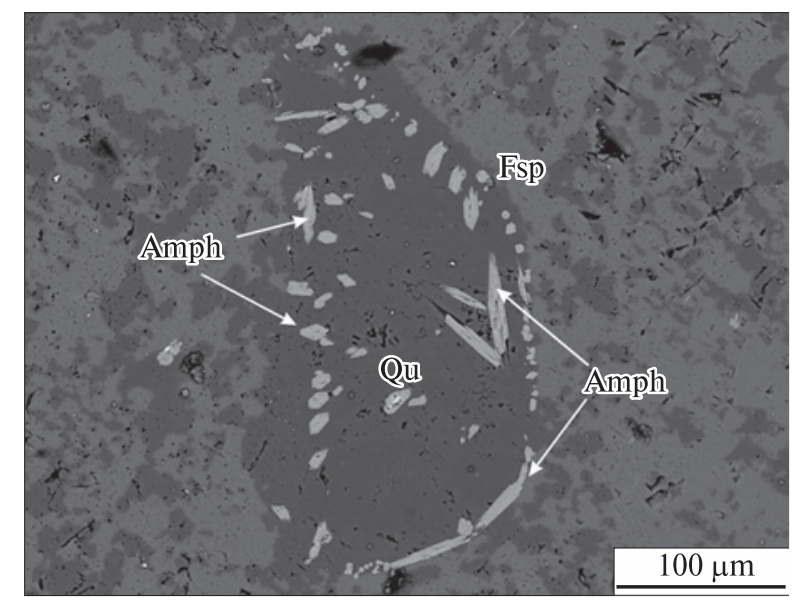

Fig. 2. Inclusions and horseshoe-shaped rim of fine-grained amphiboles $(\mathrm{Amph})$ in rounded quartz $(\mathrm{Qu})$

$0.29 \% \mathrm{~K}_{2} \mathrm{O}$ and $5.55 \% \mathrm{MnO}$ ) is also presented. Amphiboles of such composition were previously regarded as members of winchite-richterite series and probably were described as richterite [12].

In aegirine type grorudites, enrichment in $\mathrm{TiO}_{2}$ (1 to $2.2 \%)$ and significant range of $\mathrm{CaO}(0.5$ to $4.6 \%$ ) were revealed in aegirine. Early aegirine phenocrysts contain increased amount of hedenbergite component, whereas iron in aegirines from the groundmass is completely oxidized.

Additionally, unknown textural relationships (intergrowth) of aegirine and alkaline amphibole (Figs. 3, 4) in aegirine grorudites have been revealed. These intergrowths of two minerals have elongated shape $(\sim 100 \mu \mathrm{m})$ with acute-angled branches where the central part is presented by alkaline amphibole

Table 2. Chemical compositions of mafic minerals in aegirine grorudites (EDS, wt.\%)

\begin{tabular}{|l|c|c|c|c|r|r|r|r|r|r|}
\hline \multirow{2}{*}{ Component } & \multicolumn{4}{|c|}{ Aegirine } & \multicolumn{7}{c|}{ Amphibole } \\
\cline { 2 - 10 } & 1 & 2 & 3 & 4 & 5 & 6 & 7 & 8 & 9 & 10 \\
\hline $\mathrm{SiO}_{2}$ & 53.13 & 53.21 & 53.72 & 52.61 & 54.77 & 54.78 & 55.74 & 50.51 & 48.95 & 51.17 \\
$\mathrm{TiO}_{2}$ & 4.00 & 1.37 & 2.68 & 1.88 & 1.98 & 1.83 & 0.41 & - & 2.67 & - \\
$\mathrm{Al}_{2} \mathrm{O}_{3}$ & - & 1.55 & - & 0.63 & 0.62 & 0.10 & 0.20 & 0.09 & 0.39 & 0.34 \\
$\mathrm{FeO}$ & 27.82 & 29.12 & 27.91 & 29.02 & 20.04 & 19.93 & 21.46 & 38.53 & 35.32 & 37.36 \\
$\mathrm{MnO}$ & - & - & - & - & 1.66 & 1.70 & 5.55 & 0.44 & 0.60 & - \\
$\mathrm{MgO}$ & - & 1.98 & - & - & 8.64 & 8.83 & 6.16 & - & - & - \\
$\mathrm{CaO}$ & - & 0.82 & 1.20 & 0.61 & 1.11 & 0.93 & 5.87 & - & 1.43 & - \\
$\mathrm{Na}$ & 15.04 & 11.96 & 14.48 & 15.26 & 10.08 & 10.80 & 3.81 & 7.42 & 8.96 & 8.01 \\
$\mathrm{~K}_{2} \mathrm{O}$ & - & - & - & - & 1.10 & 1.10 & 0.81 & 3.01 & 1.70 & 3.12 \\
Total & 100.00 & 100.00 & 100.00 & 100.00 & 100.00 & 100.00 & 100.00 & 100.00 & 100.00 & 100.00 \\
\hline
\end{tabular}

$\mathrm{N}$ o t e. 1 - a small inclusion in titaniferous hematite; 2 - a small inclusion in titaniferous hematite with rounded zircon grains (Fig. 5,c); 3 - a small aegirine overgrowing (replacement ?) of amphibole (Fig. 4); 4 - the same (Fig. 3); 5, 6 the central part of amphibole grain with heterogeneous texture (Fig. 1); 7 - lighter area of the same crystal; 8, $10-$ earlier grains of amphibole that are overgrown (or replaced) by aegirine (Figs. 3 and 4, respectively); 9 - small amphibole grain that occur as small inclusions and horseshoe-shaped rim around the "large" quartz grain (Fig. 2). 


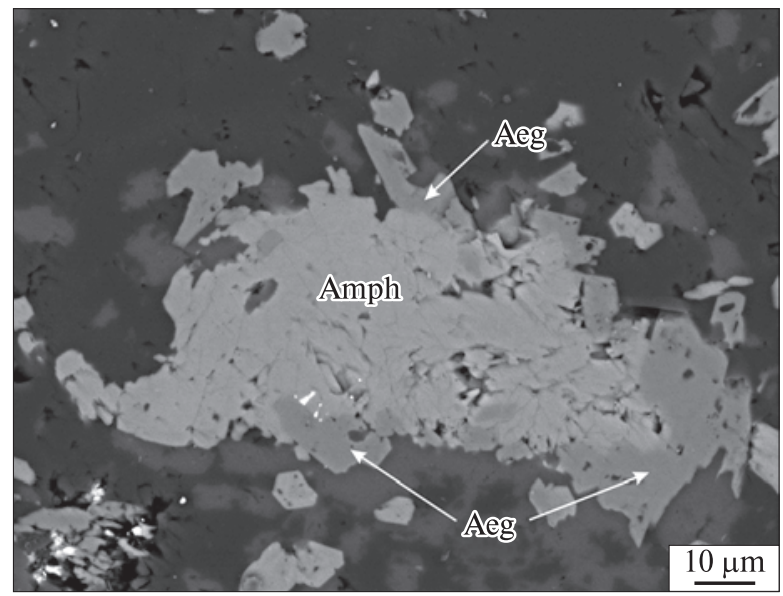

Fig. 3. Amphibole grain (Amph) with irregular aegirine $\operatorname{rim}(\mathrm{Aeg})$

whereas periphery part by interrupted aegirine rim. It seems that aegirine develops (partial replacement or overgrowth) after primary arfvedsonite (Table 2). Content and degree of Fe oxidation may explain the complex textural relationships between $\mathrm{Na}-\mathrm{Ca}$-amphiboles and aegirine (aegirine rims around amphibole grains, Figs. 3, 4). Similar replacement of $\mathrm{Na}-\mathrm{Ca}$-amphibole by aegirine was observed in alkaline granites of the Strange Lake, which was explained by liberation of aqueous fluid at the final stages of crystallization with its subsequent interaction with the rocks [36]. In addition, some amphiboles of grorudites, especially $\mathrm{Ca}-\mathrm{Na}$-varieties, are rich in $\mathrm{MgO}$, which may be due to the early amphibole crystallization from the less differentiated melt compared to late aegirine in the groundmass.

Titanium minerals. Previous investigations [7] did not reveal any significant amount of titanium minerals, the presence of which could explain the high titanium content (up to $1.43 \% \mathrm{TiO}_{2}$ ) in aegirine grorudites. Rare ilmenite and rutile were mentioned, and presence of hematite with high Ti con-

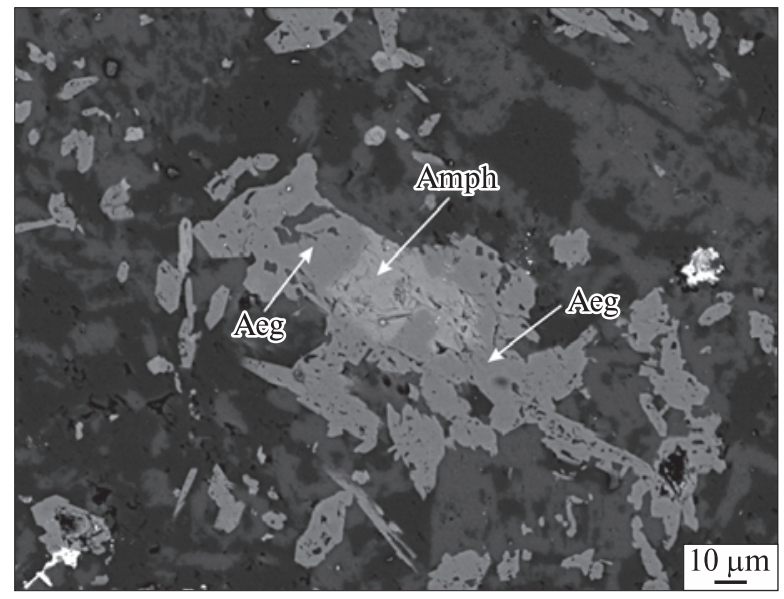

Fig. 4. Textural relationships between arfvedsonite (Amph) and aegirine (Aeg) in aegirine grorudite

tent was assumed. It is possible that grorudites, as it is common for many pantellerites, also contain aenigmatite, since high concentration of $\mathrm{TiO}_{2}$ (up to $6.3 \mathrm{wt} \%$ ) was found in some aegirine [12]. Numerous titaniferous hematite crystals bearing up to $7.3 \% \mathrm{TiO}_{2}$ (rarely up to $22.6 \%$ ), mineral similar to ilmenorutile and minerals of the $\mathrm{FeTiO}_{3}-$ $\mathrm{MnTiO}_{3}-\mathrm{ZnTiO}_{3}$ series were detected in aegirine grorudites. High content of $\mathrm{TiO}_{2}$ in hematite indicates high temperature of crystallization. Rare inclusions of ilmenite $\left(\mathrm{FeTiO}_{3}-\mathrm{MnTiO}_{3}-\mathrm{ZnTiO}_{3}\right.$ series) in hematite probably indicate the beginning of decomposition of solid solution.

Titaniferous hematite often forms grains of uncertain shape sized up to $0.1 \mathrm{~mm}$, rarely with fuzzy outer margins. All analyzed hematite grains are rich in $\mathrm{MnO}$ up to $6 \%$ (Table 3). In addition, these hematite grains host unusual and surprisingly frequent microscopic inclusions of aegirine, zircon, rare earth fluorocarbonates and, presumably, a mineral of aeschynite group (Fig. 5). Besides mentioned above inclusions, some hematite crystals host areas (inclusions or exsolution) of intermediate

Table 3. Chemical composition of titanium minerals in aegirine grorudites (EDS, wt.\%)

\begin{tabular}{|c|c|c|c|c|c|c|c|c|c|c|c|c|c|c|c|}
\hline \multirow{2}{*}{$\begin{array}{c}\text { Compo- } \\
\text { nent }\end{array}$} & \multicolumn{4}{|c|}{ Titaniferous hematite } & \multicolumn{2}{|c|}{$\begin{array}{l}\text { Pseudo- } \\
\text { brookite }\end{array}$} & \multicolumn{2}{|c|}{$\begin{array}{l}\text { Mn-Zn- } \\
\text { Ilmenite }\end{array}$} & \multicolumn{7}{|c|}{ Rutile } \\
\hline & 1 & 2 & 3 & 4 & 5 & 6 & 7 & 8 & 9 & 10 & 11 & 12 & 13 & 14 & 15 \\
\hline $\mathrm{TiO}_{2}$ & 6.79 & 17.25 & 16.95 & 22.63 & 66.37 & 69.84 & 51.74 & 50.86 & 98.56 & 94.3 & 94.69 & 94.1 & 92.2 & 92.3 & 92.37 \\
\hline $\mathrm{FeO}^{2}$ & 93.21 & 76.76 & 79.01 & 72.67 & 18.04 & 19.69 & 32.20 & 32.04 & 1.44 & 1.68 & 2.25 & 2.87 & 1.05 & 1.03 & 1.13 \\
\hline $\mathrm{MnO}$ & - & 5.99 & 4.04 & 4.70 & 4.65 & 3.21 & 10.67 & 11.61 & - & - & - & - & - & - & - \\
\hline $\mathrm{ZnO}$ & - & - & - & - & 6.57 & 5.28 & 4.47 & 4.01 & - & - & - & - & - & - & - \\
\hline $\mathrm{Nb}_{2} \mathrm{O}_{5}$ & - & - & - & - & - & - & 0.91 & 1.49 & - & 3.99 & 3.06 & 3.05 & 6.76 & 6.65 & 6.5 \\
\hline $\mathrm{WO}_{3}$ & - & - & - & - & 4.37 & 1.97 & - & - & - & - & - & - & - & - & - \\
\hline Total & 100 & 100 & 100 & 100 & 100 & 100 & 100 & 100 & 100 & 100 & 100 & 100 & 100 & 100 & 100 \\
\hline
\end{tabular}



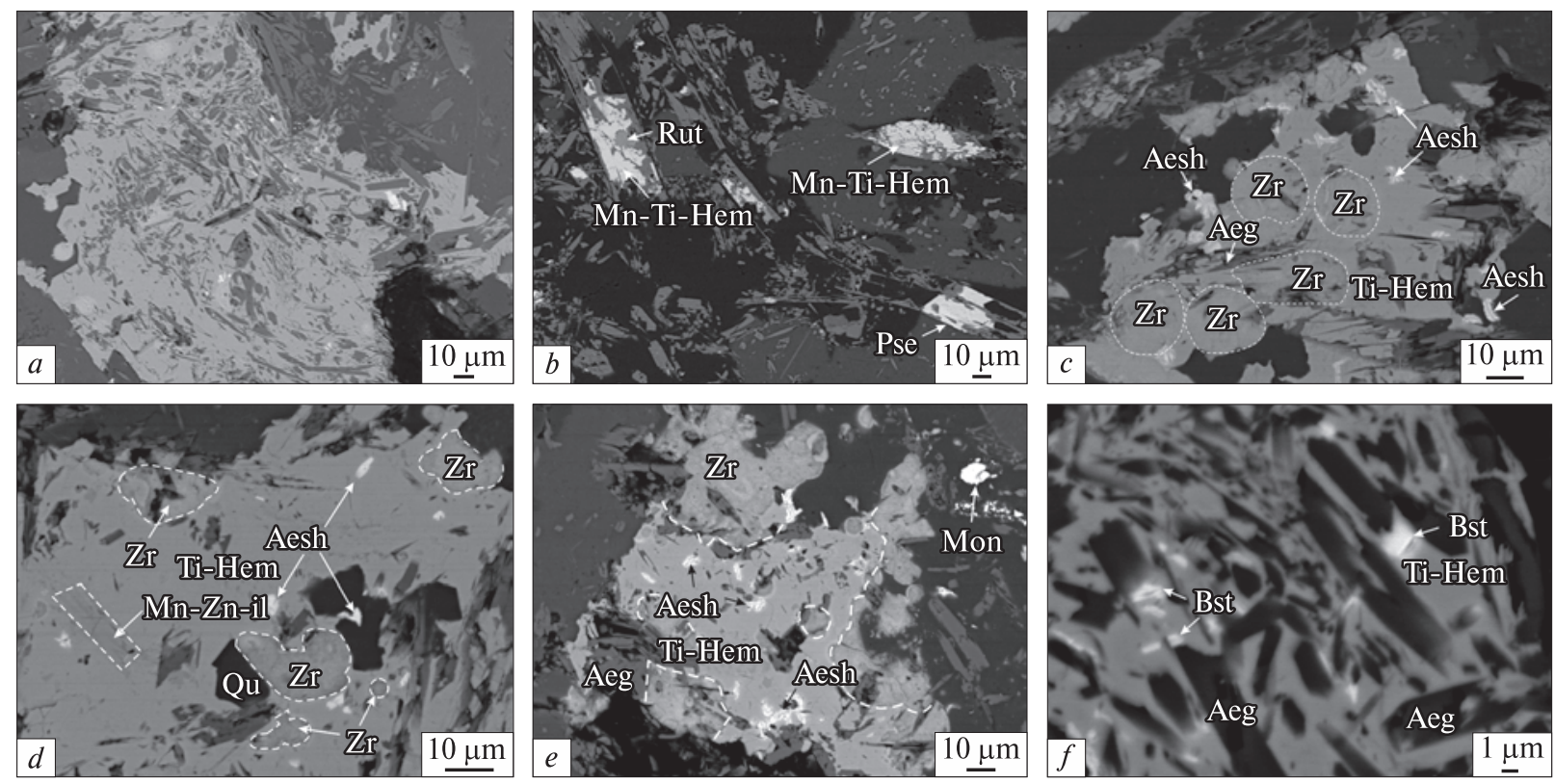

Fig. 5. Titaniferous hematite with numerous inclusions of other minerals in aegirine grorudites (BSE image). $a$ ) the segregation of titaniferous hematite grains with frequent inclusions of other minerals among which needle-like or prismatic aegirine and rare earth minerals (lighter parts) prevail; $b$ ) grains of different titanium minerals in the fine-grained groundmass. Symbols: Mn-Ti-Hem-titaniferous hematite with high content of manganese (up to 6\% MnO, Table 3), Pse - pseudobrookite with high content of $\mathrm{Zn}, \mathrm{Mn}$ and W (Table 3), Rut - rutile; $c$ ) grain of titaniferous hematite with numerous rounded zircon inclusions $(\mathrm{Zr})$, small isometric inclusions of aeschynite group (Aesh) minerals and aegirine $($ Aeg) $; d$ ) a part of titaniferous hematite (Ti-Hem) grain containing rounded zircon inclusions (hardly differ from general background of the site) and angular or irregular aegirine inclusions, Zn- and Mn-rich ilmenite (Mn-Zn-Il), small irregular or isometric inclusions of aeschynite group mineral and quartz $(\mathrm{Qu}) ; e$ ) irregularly shaped titaniferous hematite with irregular or rounded zircon inclusions which are presumably at grain margin. Also, isometric or elongated inclusions of aeschynite group minerals and needle-like and prismatic aegirines are present. At the peripheral part of image isometric grain of monazite (Mon) is observed; $f$ ) the magnified fragment of titaniferous hematite grain with numerous inclusions aegirine and bastnäsite (Bst).The white dashed lines indicate the boundaries of the rounded zircon grains

chemical composition containing $23-25$ mol. \% $\mathrm{MnTiO}_{3}$ and $7-8 \mathrm{~mol} . \% \mathrm{ZnTiO}_{3}$, with increased content of $\mathrm{Nb}_{2} \mathrm{O}_{5}(0.9-1.49 \%)$ (Fig. 5).

Isolated small $(20 \mu \mathrm{m})$ grains of titanium mineral very similar by $\mathrm{Ti} / \mathrm{Fe}$ ratio to pseudobrookite were also found in the groundmass. This mineral has high content of $\mathrm{ZnO}(5-7 \%), \mathrm{MnO}(3-5 \%)$ and $\mathrm{WO}_{3}$ (up to $4.4 \%$ ). It differs from the common ilmenorutile by the lack of $\mathrm{Nb}$.

Hence, all detected titanium minerals in grorudites are rich in $\mathrm{Mn}, \mathrm{Zn}$ and partly $\mathrm{Nb}$, that is common for minerals of alkaline rocks and fenites of this region (the Dmytrivka open pit). Both aegirine- and amphibole-bearing grorudites host rutile which contains up to $6.6 \% \mathrm{Nb}_{2} \mathrm{O}_{5}$. Taking into account that aegirine is the most abundant mafic mineral in the rock and it is rich in titanium (up to $4.26 \% \mathrm{TiO}_{2}$ ), it must be considered as important titanium mineral too.

Increased $\mathrm{MnO}$ and $\mathrm{ZnO}$ content in the mineral of ilmenite-pyrophanite series as well as in some amphiboles is a typical feature of minerals from agpaitic rocks and is related to the so-called $\mathrm{Zn}$ Mn-trend of their evolution. Such enriched in $\mathrm{Zn}$ and $\mathrm{Mn}$ minerals (Zn-kupletskite, hendricksite, serandite, Mn-taramite, Mn-annite, pyrophanite, ecandrewsite) have been described in various rocks of the Oktyabrsky massif and alkaline metasomatites of the Eastern Azov region [2].

Accessory minerals. As was noted in previous publications [7, 12], grorudites of high-Ti aegirine type are richer in REE, $\mathrm{Zr}, \mathrm{Nb}$ than the low- $\mathrm{Ti}$ ones (Table 1). It is also reflected in the amount of accessory minerals in these rocks. An aeschynite group mineral, Na-enriched calciocatapleiite, monazite-(Ce), bastnäsite-(Ce), britholite-like mineral, rare-earth apatite, zircon and unidentified $\mathrm{Zr}$ mineral were observed in high- $\mathrm{Ti}$ aegirine grorudites. Furthermore, zircon and $\mathrm{Nb}$-bearing rutile were found only in amphibole grorudites. All these minerals are very small in size, the largest of them reaching $15-20 \mu \mathrm{m}$ (rarely up to $50 \mu \mathrm{m}$ ), but most of them do not exceed $10 \mu \mathrm{m}$ (commonly 5-6 $\mu \mathrm{m}$ ) (Figs. 5, 6). Most grains or inclusions of these ISSN 2519-2396. Mineral. Journ. (Ukraine). 2020. 42, No 1 


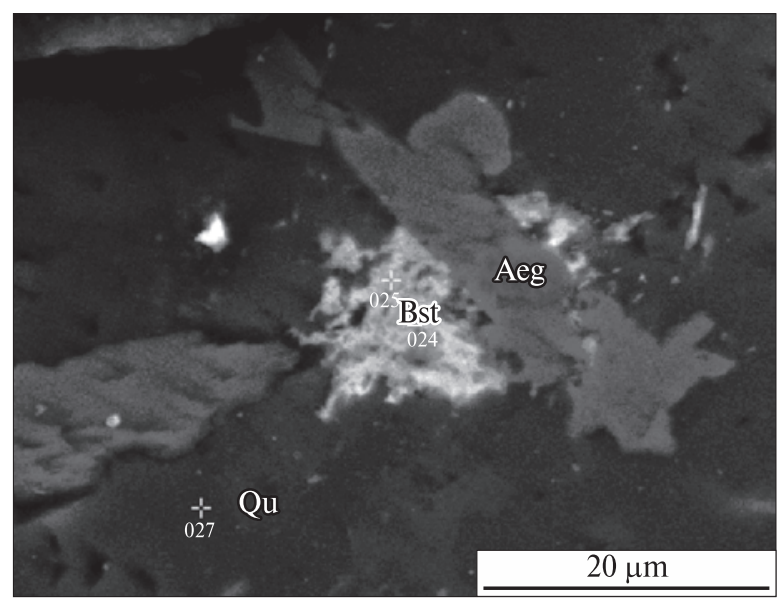

Fig. 6. Intergrowth of small fibrous bastnäsite-(Ce) (Bst) with aegirine (Aeg)

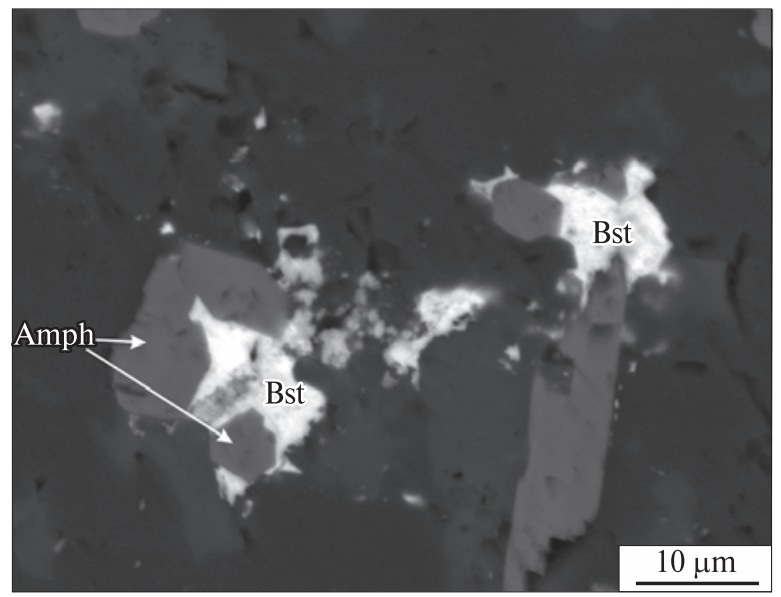

Fig. 7. Anhedral bastnäsite-(Ce) (Bst) grains in association with alkaline amphibole (Amph)

minerals are completely unhedral, and only some of their sections appear tetrahedrally or prismatic. Rare-earth fluorocarbonates mainly bastnäsite(Ce), rarely parisite-(Ce) are the most common rare earth minerals; other minerals are monazite(Ce), rare britholite-like mineral and rare earth apatite (Table 4).

Bastnäsite-(Ce) often forms small intergranular grains, the largest of which does not exceed $5 \mu \mathrm{m}$ (Figs. 6, 7); rarely do they occur as inclusions in the central parts of aegirine grains (Fig. 8). Quite often numerous of bastnäsite- $(\mathrm{Ce})$ inclusions in association with rare parisite- $(\mathrm{Ce})$ are observed in titaniferous hematite (Figs. 5, $f$; 9). Due the tiny size of these inclusions the high content of some components $(\mathrm{Si}, \mathrm{Fe})$ is probably caused by capture from the host mineral. As it is common for the studied grorudites, LREE predominate in bastnäsite(Ce) composition, while $\mathrm{Y}_{2} \mathrm{O}_{3}$ content is low (0.6-

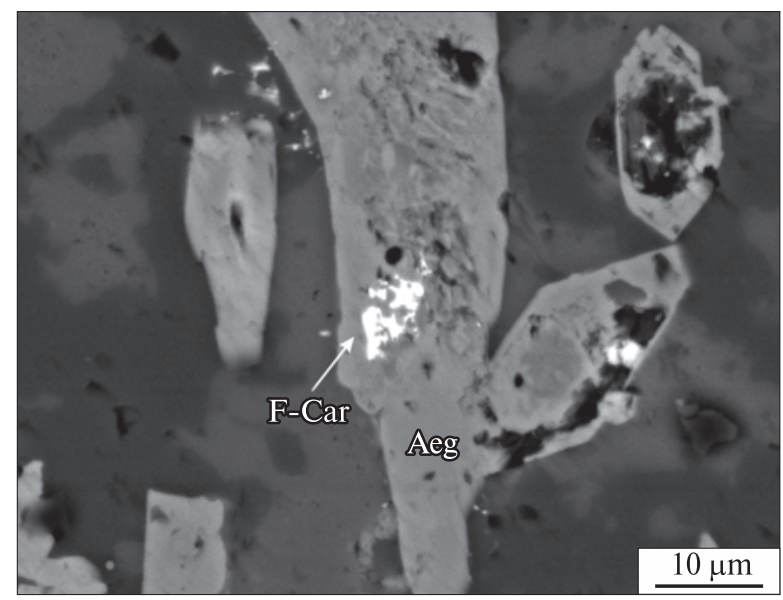

Fig. 8. Fine-grained inclusions of rare earth F-carbonate (F-Car) in the central part of the prismatic aegirine (Aeg)

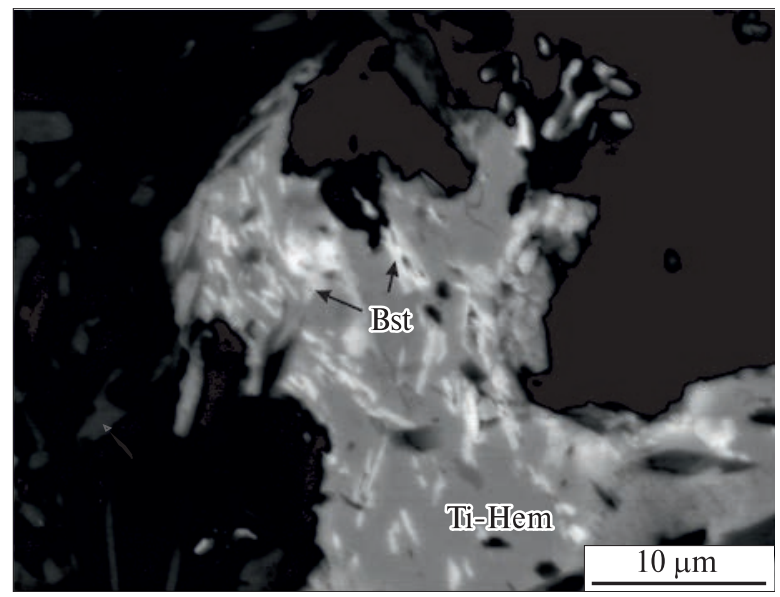

Fig. 9. A part of titaniferous hematite (Ti-Hem) grain with abundant fine and elongated inclusions of bastnäsite-(Ce) (Bst)

$1.2 \mathrm{wt} \%$, Table 4, an. 1-3). Yttrium minerals have not been found in grorudites.

The second most common rare earth mineral is monazite-(Ce) which often occurs as isolated small $(10-15 \mu \mathrm{m})$ prismatic grains and sometimes in aggregates. These small grains of monazite-(Ce) seem to be intergrowths with bastnäsite-(Ce) and possibly britholite-(Ce) (according to the presence of $\mathrm{SiO}_{2}$ ) (Table 4). Larger monazite grains possess increased $\mathrm{CaO}$ content (up to $4.9 \%$ ), rarely $\mathrm{PbO}$ (2.1\%) or $\mathrm{ThO}_{2}$ (up to $4.5 \%$ ). These chemical characteristics of Ca-bearing monazite-(Ce) are very similar to cheralite that was mentioned previously [12].

The britholite-like mineral (Table 4) as most other accessory minerals occurs as rare small grains reaching 5-10 $\mu \mathrm{m}$ in size, which are often located at the marginal parts of aegirine crystals or very close to them. These grains are heterogeneous 


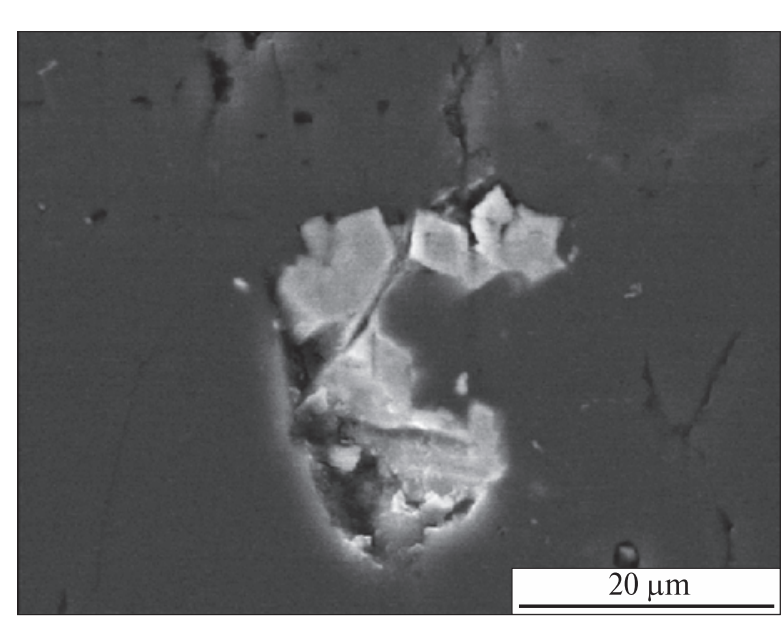

Fig. 10. Accumulation of small diamond-shaped zircon crystals possibly formed by replacement of primary CaNa-zirconosilicates

and likely form thin ingrowths with bastnäsite-(Ce) or, more likely, with monazite since high concentrations of phosphorus (up to $1.65 \% \mathrm{P}_{2} \mathrm{O}_{5}$ ) and $\mathrm{Pb}$ (up to $1.1 \% \mathrm{PbO}$ ) were observed in some analyzes. As mentioned above, an increased content of $\mathrm{PbO}$ was recorded in some analyzes of monazite-(Ce). The britholite-like mineral has a slightly lower concentration of $\mathrm{CaO}(2.69-3.95 \%)$ and LREE substantially prevail over HREE.

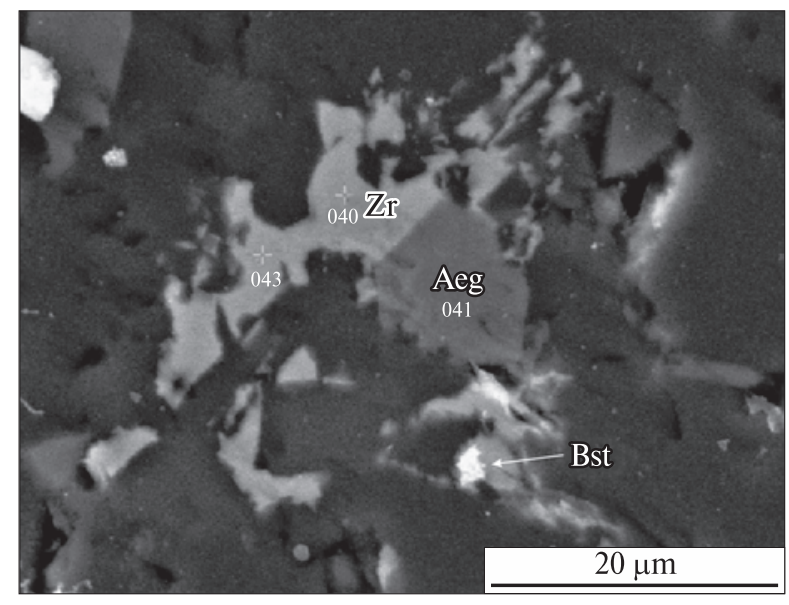

Fig. 11. Intergrowth of high-Y zircon $(\mathrm{Zr})$ with aegirine (Aeg)

REE apatite is extremely rare in the investigated grorudites because of their low $\mathrm{CaO}(0.2-$ $0.4 \mathrm{wt} \%$, up to $1.7 \mathrm{wt} \%$ in one sample) and $\mathrm{P}_{2} \mathrm{O}_{5}$ (0.03-0.09 wt \%) content. Only one heterogeneous irreular grain, $6 \times 10 \mu \mathrm{m}$ in size, has been discovered. Considering the high REE concentration, it is possible that it consists of tiny intergrowths of apatite with bastnäsite. However, the matrix of this grain has high $\mathrm{CaO}(29.43 \mathrm{wt} \%)$ and $\mathrm{P}_{2} \mathrm{O}_{5}(36.57 \mathrm{wt} \%)$ contents, and we consider this

Table 4. Chemical composition of accessory rare metal minerals (WDS + EDS, wt.\%)

\begin{tabular}{|c|c|c|c|c|c|c|c|c|c|c|c|c|c|c|c|c|}
\hline nent & 1 & 2 & 3 & 4 & 5 & 6 & 7 & 8 & 9 & 10 & 11 & 12 & 13 & 14 & 15 & 16 \\
\hline & & - & - & & & & & & 36.56 & 42.89 & 37.37 & 39.14 & 37.13 & 32.84 & 36.24 & 30.71 \\
\hline & .62 & - & - & 89 & 3.16 & 45 & 1.29 & 2.13 & 3.30 & 4.23 & 1.28 & 0.94 & 2.78 & 0.98 & 3.88 & 3.05 \\
\hline & 4. & - & - & 4.92 & 1.41 & 3.2 & 0.69 & 3.56 & 2.21 & 9. & 8.8 & 15.52 & & & 35 & 5.05 \\
\hline $\mathrm{CaO}$ & & 5.48 & 5.44 & 4.93 & & & & & & & & & & & & 1.2 \\
\hline $\mathrm{K}_{2} \mathrm{O}$ & 0.24 & - & - & - & - & - & & - & - & - & & 0.16 & & & 1.99 & 1.35 \\
\hline $\mathrm{P}_{2} \mathrm{O}_{5}$ & - & - & - & 24.39 & 0.02 & 1.65 & 36.57 & - & - & - & - & - & - & - & - & - \\
\hline F & - & 3.79 & 4.55 & - & - & - & - & - & - & - & - & - & - & - & - & - \\
\hline $\mathrm{PbO}_{2}$ & 0.77 & - & - & 2.09 & - & 1.11 & - & 0.6 & 0.85 & 0.24 & - & 1.89 & - & - & 0.7 & 0.25 \\
\hline $\mathrm{Y}_{2} \mathrm{O}_{3}$ & & - & - & - & 0.45 & & 0.47 & 1.47 & 1.8 & 1.53 & 2.10 & 1.24 & 7.80 & 8.40 & 2.2 & 1.9 \\
\hline $\mathrm{La}_{2} \mathrm{O}_{3}$ & 13.07 & 19.77 & 19.19 & 9.48 & 12.15 & & 4.52 & - & 0.1 & 0.24 & - & .19 & - & - & 2 & 1.75 \\
\hline $\mathrm{Ce}_{2} \mathrm{O}_{3}$ & 24.92 & 44.55 & 44.07 & 21.52 & 27.1 & 27.38 & 14.37 & 0.15 & 0.17 & 0.65 & - & 0.89 & - & - & 0.45 & 3.69 \\
\hline $\mathrm{Pr}_{2} \mathrm{O}_{3}$ & 2.38 & 8.5 & 8.91 & 1.79 & 2.72 & 2.51 & 1.01 & - & - & - & - & - & - & - & - & - \\
\hline $\mathrm{Nd}_{2} \mathrm{O}_{3}$ & 9.47 & 17.95 & 17.8 & & & & & - & - & - & 0.01 & 0.63 & - & - & 0.20 & 1.35 \\
\hline $\mathrm{Gd}_{2} \mathrm{O}_{3}$ & & - & - & 0.65 & 0.87 & 0.91 & 0.29 & - & - & - & - & - & - & - & - & - \\
\hline $\mathrm{Dy}_{2} \mathrm{O}_{3}$ & 0 & - & - & 0.14 & 0.36 & - & 0.12 & - & - & - & - & - & - & - & - & - \\
\hline $\mathrm{Th}_{2} \mathrm{O}_{3}$ & & - & - & 1.94 & & & & - & - & - & - & - & - & - & 0.72 & 0.4 \\
\hline $\mathrm{UO}_{2}$ & 0.51 & - & - & 1.39 & 0.31 & 1.33 & 0.53 & 1.83 & 1.5 & 2.28 & 2.31 & 0.74 & - & - & - & 0.26 \\
\hline $\mathrm{ZrO}_{2}$ & - & - & - & - & - & - & - & 50.8 & 40.29 & 32.36 & 33.57 & 38.62 & 50.23 & 54.84 & 38.14 & 35.93 \\
\hline $\mathrm{Nb}_{2} \mathrm{O}_{5}$ & - & - & - & - & - & - & - & 0.37 & 1.15 & 0.65 & 0.87 & 0.92 & - & - & 1.40 & 1.62 \\
\hline Total & 72.21 & $100 *$ & $100 *$ & 97.38 & 76.55 & 78.96 & 101.73 & 96.3 & 90.56 & 95.67 & 88.14 & 102.4 & 99.99 & 100.00 & 88.78 & 88.64 \\
\hline
\end{tabular}

$\mathrm{N}$ o t e. $*$ - total is presented as $100 \%$. 1-3 - bastnäsite-(Ce); $4-$ monazite-(Ce), $1.94 \% \mathrm{SO}_{3}$ is included in the total; 5, 6 - britholite-like mineral; 7 - rare earth apatite; 8-12 - zircon; 13, 14 - Y-enriched zircons; 15, 16 - unidentified zirconium minerals rich in $\mathrm{Y}$ and $\mathrm{Nb}$. 
grain as apatite (Table 4) with a high REE content (26.3 wt \% total REE) and significant predominance of LREE (14.37 wt \% of $\mathrm{Ce}_{2} \mathrm{O}_{3}$ ). The high content of REE, as well as the increased concentrations of radioactive elements, may also indicate partial capture of other minerals, like bastnäsite- $(\mathrm{Ce})$ or monazite- $(\mathrm{Ce})$ by the microprobe beam.

Zirconium minerals are zircon, Na-enriched calciocatapleiite and rarely an unidentified zirconium mineral (36-38 wt \% $\mathrm{ZrO}_{2}$, Table 4) with increased content of $\mathrm{Nb}_{2} \mathrm{O}_{5}, \mathrm{Y}_{2} \mathrm{O}_{3}, \mathrm{UO}_{2}$, in some analyzes REE.

Zircon forms small grains of irregular shape, rarely there are aggregates (Fig. 10) and numerous small rounded inclusions in titaniferous hematite. These inclusions hardly distinguishable from the titaniferous hematite matrix in $B S E$-images (Fig. 5, c-e). In some grains of hematite such inclusions can occupy a considerable part of the mineral-matrix (Fig. 5,c). Some zircon grains contain up to $8.4 \mathrm{wt} \% \mathrm{Y}_{2} \mathrm{O}_{3}$ (Fig. 11).

In one aegirine grorudite sample, a mineral containing $\mathrm{Zr}, \mathrm{Ca}$ and $\mathrm{Na}$ was discovered. By the chemical composition it is close to minerals of the calciocatapleiite $\left(\mathrm{CaZr}\left(\mathrm{Si}_{3} \mathrm{O}_{9}\right) \cdot 2 \mathrm{H}_{2} \mathrm{O}\right)$ - catapleiite $\left(\mathrm{Na}_{2} \mathrm{Zr}\left(\mathrm{Si}_{3} \mathrm{O}_{9}\right) \cdot 2 \mathrm{H}_{2} \mathrm{O}\right)$ series (Fig. 12). A general formula is $\mathrm{Na}_{x} \mathrm{Ca}_{1-0.5 x} \mathrm{Zr}\left(\mathrm{Si}_{3} \mathrm{O}_{9}\right) \cdot 2 \mathrm{H}_{2} \mathrm{O}$, where $x$ can reach a maximum of 2 (i.e. catapleiite). Possible minerals are hilairite $\left(\mathrm{Na}_{2} \mathrm{Zr}\left[\mathrm{SiO}_{3}\right]_{3} \cdot 3 \mathrm{H}_{2} \mathrm{O}\right)$,

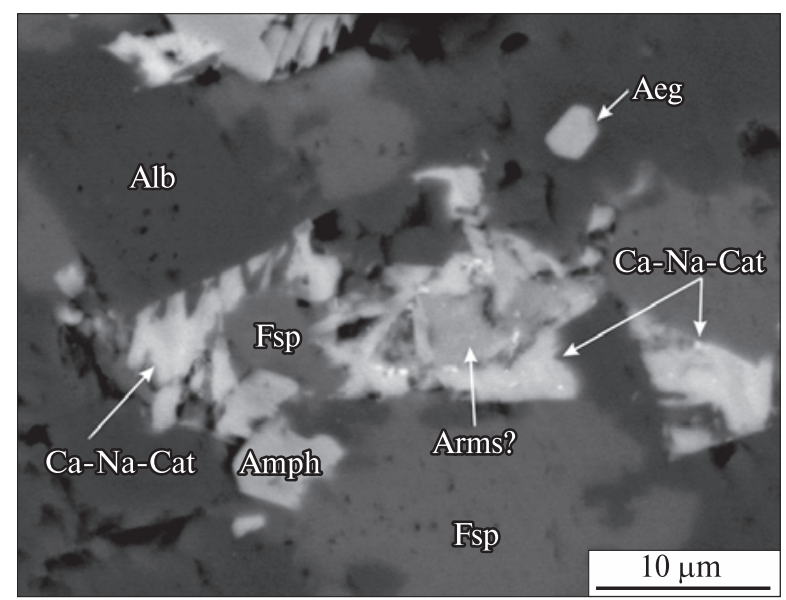

Fig. 12. An aggregate of $\mathrm{Ca}-\mathrm{Na}-\mathrm{Zr}$-silicates of catapleiitegroup (Ca-Na-Cat) and armstrongite (Arms ?) in albite (Alb)-microcline (Fsp) groundmass

calciohilairite $\left(\mathrm{CaZr}\left[\mathrm{SiO}_{3}\right]_{3} \cdot 3 \mathrm{H}_{2} \mathrm{O}\right)$, gaidonnayite $\left(\mathrm{Na}_{2} \mathrm{Zr}\left[\mathrm{SiO}_{3}\right]_{3} \cdot 2 \mathrm{H}_{2} \mathrm{O}\right)$, keldyshite $\left.(\mathrm{Na}, \mathrm{H})_{2} \mathrm{ZrSi}_{2} \mathrm{O}_{7}\right)$ or parakeldyshite $\left(\mathrm{Na}_{2} \mathrm{ZrSi}_{2} \mathrm{O}_{7}\right)$. This catapleiite mineral requires more accurate investigation together with evaluation of its water content.

Furthermore it is observed in aggregates or intergrowth with $\mathrm{Ca}-\mathrm{Na}-\mathrm{Zr}$-silicate, in which $\mathrm{Zr}$ : $\mathrm{Si}$ ratio is about $1: 6$, and the sum (p.f.u.) of $\mathrm{Ca}+$ $+\mathrm{Na}$ is 1.15 (Ca 0.77 and $\mathrm{Na} 0.34$ ). Such Narich calciocatapleiite forms small individual grains $(<10 \mu \mathrm{m})$ of irregular shape or their segregation in albite-feldspar groundmass. This mineral is

Table 5. Composition of Ca-Na-Zr-silicates and aeschynite group minerals (EDS, wt.\%)

\begin{tabular}{|l|c|c|c|c|c|c|c|c|c|}
\hline \multirow{2}{*}{ Component } & \multicolumn{3}{|c|}{ Ca-Na-Zr-sillicates } & \multicolumn{7}{c|}{ Aeschynite group } \\
\cline { 2 - 9 } & 1 & 2 & 3 & 4 & 5 & 6 & 7 & 8 & 9 \\
\hline $\mathrm{SiO}_{2}$ & 52.35 & 53.27 & 67.75 & 8.51 & 17.26 & - & 7.28 & 7.86 & 2.37 \\
$\mathrm{TiO}_{2}$ & 1.01 & 0.88 & - & 43.1 & 41.08 & 43.63 & 44.26 & 47 & 45.01 \\
$\mathrm{ZrO}_{2}$ & 29.83 & 28.76 & 18.04 & - & - & - & - & - & - \\
$\mathrm{Al}_{2} \mathrm{O}_{3}$ & 0.98 & 0.47 & 2.37 & - & - & - & - & - & - \\
$\mathrm{FeO}$ & 1.38 & 1.05 & 2.23 & 4.21 & 3.59 & 15.35 & 16.39 & 14.57 & 18.55 \\
$\mathrm{CaO}$ & 1.47 & 12.23 & 7.45 & 1.48 & 1.01 & - & 1.24 & 1.87 & - \\
$\mathrm{Na}_{2} \mathrm{O}$ & 2.99 & 3.33 & 1.81 & - & - & - & - & - & - \\
$\mathrm{Y}_{2} \mathrm{O}_{3}$ & - & - & - & - & - & 5.44 & - & - & - \\
$\mathrm{Ce}_{2} \mathrm{O}_{3}$ & - & - & - & 16.83 & 12.67 & - & - & - & 14.1 \\
$\mathrm{Nd}_{2} \mathrm{O}_{3}$ & - & - & - & 17.52 & 16.35 & 14.6 & 20.32 & 20.32 & 15.61 \\
$\mathrm{Gd}_{2} \mathrm{O}_{3}$ & - & - & - & - & - & 5.05 & 4.10 & - & - \\
$\mathrm{ThO}_{2}$ & - & - & - & - & - & 8.47 & - & - & - \\
$\mathrm{Nb}_{2} \mathrm{O}_{5}$ & - & - & - & 8.35 & 8.04 & 4.98 & 6.42 & 8.38 & 4.36 \\
$\mathrm{Ta}_{2} \mathrm{O}_{5}$ & - & - & - & - & - & 2.48 & - & - & - \\
Total & 100 & 100 & 100 & 100 & 100 & 100 & 100 & 100 & 100 \\
\hline
\end{tabular}

$\mathrm{N}$ o t e. 1, 2 - isolated grains of Na-enriched Ca-catapleiite; 3 - a mineral similar to armstrongite (Fig. 12); 4-9 small inclusions in titaniferous hematite grains. 
characterized by moderate $\mathrm{Na}_{2} \mathrm{O}$ and the highest $\mathrm{CaO}$ content in comparison with other, even rockforming, minerals. The mineral of such composition is inherent for agpaitic rocks and, in our opinion, it belongs to a primary zirconium mineral of grorudites. The Ca-Na-Zr-silicate in association with calciocatapleiite usually occupies the central part of aggregate, periphery of which is replaced by calciocatapleiite (Fig. 12). According to the formulae units of $\mathrm{Ca}+\mathrm{Na}, \mathrm{Zr}$, and $\mathrm{Si}$ (calculation on the base of 9 cations), this $\mathrm{Ca}-\mathrm{Na}-\mathrm{Zr}$-silicate is very similar to armstrongite $\left(\mathrm{CaZr}\left[\mathrm{Si}_{6} \mathrm{O}_{15}\right] 3 \mathrm{H}_{2} \mathrm{O}\right)$.

As to the third zirconium mineral, it could not be analyzed accurately considering its extremely small size (up to $10 \mu \mathrm{m}$ ) and it needs to be studied further. According to the available analyses (Table 4), Si prevails over $\mathrm{Zr}+\mathrm{Y}+\mathrm{Nb}$ with a ratio of $1.4: 1$ to $2.2: 1$ in this mineral. The mineral could be classified as hagatalite (due to a high content of $\mathrm{Nb}$, Y, sometimes REE, U), although the predominance of $\mathrm{Si}$ over $\mathrm{Zr}$ approximates it to gittinsite with low $\mathrm{CaO}$ content.

Apparently, Zr-minerals, at least a part of them, replaced primary $\mathrm{Na}$-(eudialite, catapleiite, hilairite) or $\mathrm{Ca}$-(gittinsite, armstrongite) $\mathrm{Zr}$-silicates, which are typical for alkali-saturated rocks. Naenriched calciocatapleiite could be one of them. For example, eudialite had been previously assumed as primary minerals in mariupolites of the Oktyabrsky massif [11], and later it was confirmed in agpaitic phonolites [10]. In recent studies [9] catapleiite relics were also found in bipyramidal zircon crystals in mariupolites. It is possible that monazite-(Ce) and bastnäsite-(Ce) in grorudites is consequence of replacement of britholite and/or aeschynite.

Niobium minerals. Although $\mathrm{Nb}$ concentration in aegirine grorudites is quite high $(110-486 \mathrm{ppm}$ by $X R F$, and up to $1218 \mathrm{ppm}$ in one analysis), $\mathrm{Nb}$ minerals in these rocks have been unknown until now. We found a single Ti-REE-Nb-oxide, which most likely corresponds to a mineral of the aeschynite group, as small $(\sim 5 \mu \mathrm{m})$ inclusions in titaniferous hematite or in its marginal parts, rarely in the groundmass (Fig. 5, c-e). It is associated with zircon and REE-carbonate and has up to 8.35 wt $\% \mathrm{Nb}_{2} \mathrm{O}_{5}$ (Table 5). $\mathrm{REE}\left(\mathrm{Ce}_{2} \mathrm{O}_{3}\right.$ and $\mathrm{Nd}_{2} \mathrm{O}_{3}$ being the more common) contents are in the order of $30 \mathrm{wt} \%$. The $(\mathrm{REE}+\mathrm{Ca}):(\mathrm{Ti}+\mathrm{Nb})$ ratio in this minerals is close to $1: 2$ and quite similar to the minerals of aeschynite group. The high $\mathrm{Fe}$ content in some analyses is an artifact caused by overlapping analyses with host titaniferous hematite; $\mathrm{FeO}$ content in the mineral located outside of hematite does not exceed 4 wt. \% which is common for aeschynite [6].

An increased $\mathrm{Nb}$ content was recorded in a mineral of ilmenite-pyrophanite series in aegirine grorudite. In contrast, in the sample of amphibole grorudite with medium $\mathrm{Nb}$ concentration $(88 \mathrm{ppm}$ by $I C P-M S$ or $133 \mathrm{ppm}$ by $X R F)$, only rutile with $6.76 \% \mathrm{Nb}_{2} \mathrm{O}_{5}$ was found (Table 3). Such rutile occurs as inclusions in hematite (up to $3.82 \% \mathrm{TiO}_{2}$ ) or is present among quartz. It is possible that a significant or even prevailing part of $\mathrm{Nb}$ is isomorphically scattered in other minerals, such as in the unidentified $\mathrm{Zr}$-mineral.

A possible relationship of trace-element minerals and titaniferous hematite. To the best of our knowledge, these unusual exsolution (?) textures of rare minerals in titaniferous hematite have not been found in other alkaline granite complexes. Therefore, all our further arguments regarding the possible origin of the close association (intergrowth, inclusions) of HFSE-mineralization with titaniferous hematite in grorudites are based mainly on the crystallization conditions of hematite and experimental studies of trace elements' distribution in silicate melts. As noted above, titaniferous hematite grains are usually anhedral and often contain numerous small inclusions of needle-like aegirine and HFSE-minerals. We take this as an argument for late crystallization, possibly from the residual and low-Ti and Fe-rich melt (or individual melt droplets) close in composition to hematite. Assuming such a residual melt, the redistribution of a number of trace elements into this melt is also quite probable. The experimental data of [28] can partly support this model. According to these authors, partition coefficients of trace-elements in the $\mathrm{Fe}_{2} \mathrm{SiO}_{4}$ $\mathrm{Fe}_{3} \mathrm{O}_{4}-\mathrm{KAlSi}_{2} \mathrm{O}_{6}-\mathrm{SiO}_{2}, \mathrm{Fe}_{3} \mathrm{O}_{4}-\mathrm{KAlSi}_{2} \mathrm{O}_{6}-\mathrm{SiO}_{2}$, $\mathrm{Fe}_{3} \mathrm{O}_{4}-\mathrm{Fe}_{2} \mathrm{O}_{3}-\mathrm{KAlSi}_{2} \mathrm{O}_{6}-\mathrm{SiO}_{2}, \quad \mathrm{Fe}_{3} \mathrm{O}_{4}-\mathrm{Fe}_{2} \mathrm{O}_{3}-$ $\mathrm{KAlSi}_{2} \mathrm{O}_{6}-\mathrm{SiO}_{2}-\mathrm{Ca}_{0.5} \mathrm{Na}_{0.5} \mathrm{Al}_{1.5} \mathrm{Si}_{2.5} \mathrm{O}_{8}$ systems (in the presence of $\mathrm{H}_{2} \mathrm{O}$ or other elements such as $\mathrm{P}, \mathrm{S}$, $\mathrm{F}$ or $\mathrm{Cl}$ ) indicate strong preference of HFSE and REE for the Fe-rich melt, in contrast to anhydrous melts of similar composition (regardless of $\mathrm{fO}_{2}$ ). This data is consistent with the results of the earlier experimental work $[34,45]$ related to the trace element partitioning between immiscible silicate liquids where trace elements were concentrated in Fe-rich melts. In Ti-rich systems, enriched in REE, $\mathrm{Y}, \mathrm{Sr}$ and $\mathrm{Nb}$, at 1200 and $1250^{\circ} \mathrm{C}$ and $P=2 \mathrm{kbar}$ in the presence of aqueous or alkaline fluid the melt also splits into two phases, an aluminosilicate 
Fig. 13. Primitive mantle normalized trace element diagrams for Devoniand rocks of the Azov region. Legend: 1 - OIB by [44]; 2, 3 - high-Ti and low-Ti grorudites, respectively; 4 - gabbro of the Pokrovo-Kyriyivo complex; 5, 6nepheline syenites of this complex

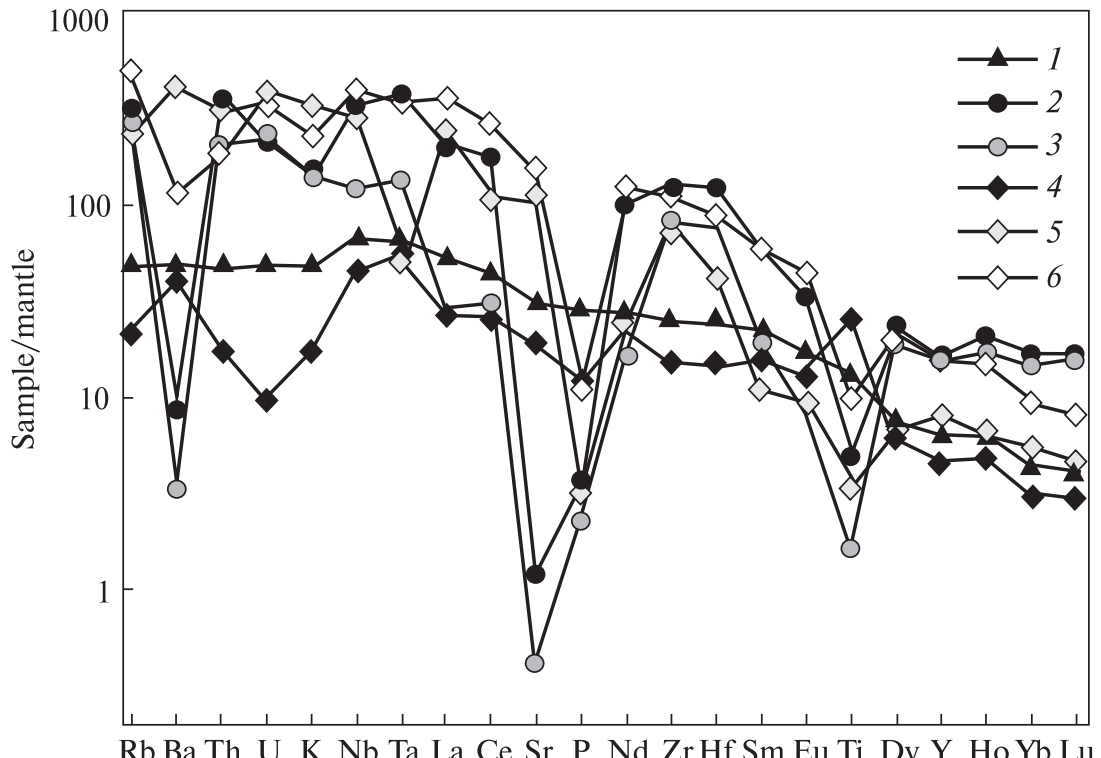

$\mathrm{Rb} \mathrm{Ba}$ Th U K Nb Ta La Ce Sr P Nd ZrHf Sm Eu Ti Dy Y Ho Yb Lu matrix and droplets enriched in Ti, REE, Y, Sr, and $\mathrm{Nb}$ [43]. Thus, in the Ti-silicate systems liquid immiscibility also leads to a significant enrichment in rare components, including $\mathrm{Zr}$, in the Ti-rich melt phase. As the temperature decreased, HFSE were expelled from titaniferous hematite with subsequent crystallization of their own minerals.

Discussion. Grorudite origin. Many authors considered that silica-oversaturated agpaitic rocks originated due to the crustal contamination of mantlederived, silica-undersaturated alkaline magmas [21, 30]. Primary silica-undersaturated alkaline melts occur as a result of partial melting of metasomatically enriched mantle under relatively dry and reducing conditions [16, 26].

Low-degree partial melting of mantle gives rise to alkali and often silica-undersaturated parent magmas, and already at the stage of melt generation the conditions for HFSE enrichment were favorable. During evolution, these melts achieve a significant enrichment in volatile components $(\mathrm{Cl}$ and $\mathrm{F}$ ) and alkali metals ( $\mathrm{Na}$ and $\mathrm{K}$ ), that considerably decreases the solidus temperatures and allows such melts to differentiate down to unusually low temperatures $\left(\sim 400{ }^{\circ} \mathrm{C}\right.$ according to $[29,39])$ before expelling fluid. It is considered that high concentrations of alkalis and fluorine increase the solubility of HFSE as well as higher proportion of non-bridging oxygen allows concentrating HFSE. So, the high concentrations of volatile components in highly evolved peralkaline magmas lead to high concentrations of highly incompatible elements.

Considering the Devonian age of grorudites, there is a reason to believe them to be the derivatives

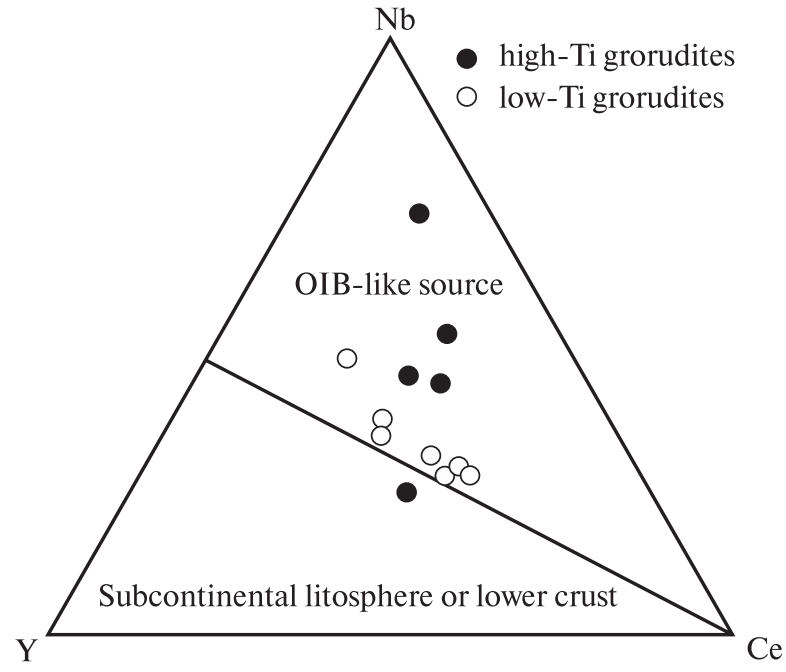

Fig. 14. Triangular Y-Nb-Ce diagram for distinguishing of different types of A-type granites [20]

of primary subalkaline basalts similar to initial melts of the Pokrovo-Kyriyivo complex [7]. High agpaitic index and low \# Mg also point to highly evolved composition of grorudites. This assumption is confirmed by high, as for granites, concentrations of $\mathrm{Ti}, \mathrm{Cr}, \mathrm{V}, \mathrm{Ni}$, possibly inherited from the primary basic melts. This caused crystallization of titaniferous hematite, ilmenite and rutile as well as aegirine with increased $\mathrm{TiO}_{2}$ content in aegirine grorudites. Samples of high-Ti and low-Ti grorudites show slightly fractionated REE patterns and moderate $\mathrm{Eu} / \mathrm{Eu}^{*}$ ratios $\left((\mathrm{La} / \mathrm{Yb})_{n} 11.5\right.$ and $1.7 ; \mathrm{Eu} / \mathrm{Eu}^{*} 0.77$ and 0.46 respectively). Primitive mantle-normalized spider-diagrams for both types of grorudites are highly enriched in trace elements compared with those of OIB and gabbro of the 


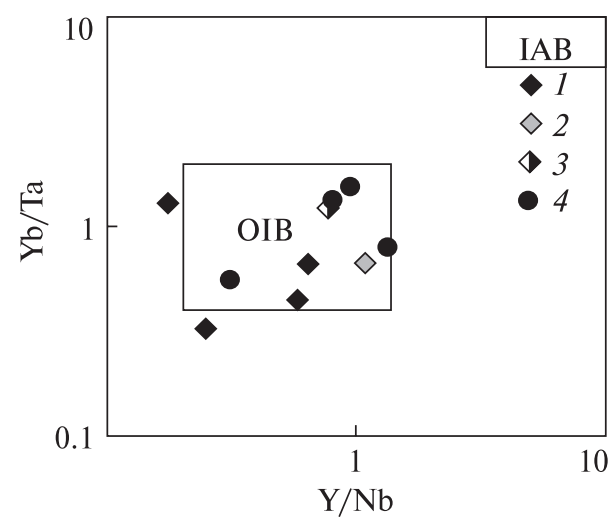

Fig. 15. $\mathrm{Yb} / \mathrm{Ta}$ vs. $\mathrm{Y} / \mathrm{Nb}$ in various A-type granitoid suites [20]. OIB - the oceanic-island basalt; IAB - island-arc basalts. Legend: 1 - basic and syenitic rocks from the Pokrovo-Kyriyivo complex; 2, 3 - essexites of the Zirka and Prymorskyi massifs respectively; 4 - grorudites

Pokrovo-Kyriyivo complex but similar to those of nepheline syenites from this complex (Fig. 13). The deep negative anomalies of $\mathrm{Ba}, \mathrm{Sr}, \mathrm{P}$ and $\mathrm{Ti}$ and enrichment by other incompatible elements are consisted with generation of alkali granitic melts during fractionation of mantle derived basaltic melts. Moreover, high- and low-Ti grorudites fall into the upper $\mathrm{A} 1$ field in the $\mathrm{Nb}-\mathrm{Y}$-Ce diagram (Fig. 14) [20], implying a source for these granites was similar to that of oceanic-island basalts. Their position within OIB field in another diagram (Fig. 15) also confirms a common source for Devonian primary basalts and grorudites of the Azov region, as well as for gabbro and essexites from other Devonian massifs of this region.

Differentiation of such primary basaltic melt at the final stages could have led to the appearance of silica-oversaturated agpaitic residual liquids of granitic composition, similar to grorudites [7].

Possible processes of HFSE concentration. Hydrothermal processes. Many researchers believe that hydrothermal processes have played a significant role in the $\mathrm{Zr}-\mathrm{Nb}-\mathrm{Y}$-REE mineralization in alkaline granitic rocks $[3,36,37]$ since there is a lot of evidences that HFSE are mobile in hydrothermal systems. An occurrence of HFSE minerals (e. g., bastnäsite and baddeleyite) in fluid inclusions is also used as a direct evidence of HFSE migration in hydrothermal fluids [27, 35]. The geochemical and mineralogical data indicate that the alterations of agpaitic acidic rocks results in the significant $\mathrm{Ca}$, F and HFSE enrichment, hematitization and silicification. Furthermore, according to the experimental data [48], $\mathrm{Zr}$ and $\mathrm{Nb}$ solubility in the hydrothermal systems is quite low, and that Ta is even less soluble than $\mathrm{Nb}$ in aqueous fluid. However, solubility and hydrothermal transfer of $\mathrm{Ta}$ and $\mathrm{Nb}$, as well as $\mathrm{Zr}$, are significantly increased by temperature and $\mathrm{F}$ (or $\mathrm{Cl}^{-}, \mathrm{CO}_{3}{ }^{2-}, \mathrm{PO}_{4}{ }^{2-}$ ) in the solution [1, 48].

Triggers for different ore-forming processes in alkali acidic rocks are not yet fully understood. For instance, the $\mathrm{Zr}, \mathrm{Nb}$, REE and $\mathrm{Y}$ enrichment in agpaitic granites of the Khaldzan deposit (Mongolia) is considered as a result of magmatic fractionation [25] or as a result of intensive secondary alteration $[3,4]$.

The absence or insignificant effect of hydrothermal alterations of grorudites is indicated by the only minor development of aegirine after amphibole, restricted appearance of rare-earth F-carbonates, rather high $\mathrm{Nb} / \mathrm{Ta}$ ratio $(\sim 15)$, low concentration (ppm) of Li (<60, rarely 250), Sn (8-12), Cs $(0.2-0.3)$ and $\mathrm{W}(0.9-1.2)$ and increased concentration of $\mathrm{Rb}(90-205)$, as well as by low (in available chemical analyses) concentration of volatile components $\left(\mathrm{H}_{2} \mathrm{O}, \mathrm{Cl}, \mathrm{F}\right.$ and $\left.\mathrm{CO}_{2}\right)$. Mentioned incompatible elements have a strong affinity for magmatic fluids, so their enrichment is commonly used as a marker of a magmatichydrothermal alteration of granites [15]. The high $\mathrm{Nb} / \mathrm{Ta}$ and $\mathrm{Zr} / \mathrm{Hf}$ ratios have been proposed as the markers of magmatic-hydrothermal interactions. In the investigated grorudites the $\mathrm{Zr} / \mathrm{Hf}$ ratio is uniform $(\sim 38)$ whereas in the granites enriched by $\mathrm{Sn}, \mathrm{Li}, \mathrm{W}, \mathrm{Nb}$ and Ta this ratio is typically $<25$. It is possible that the low content of volatiles, especially $\mathrm{F}$, may indicate quite dry conditions during crystallization or early volatile expulsion from the residual melt at hypabyssal conditions. That may explain the absence or insignificant occurrence of secondary HFSE mineralization or immobility of these elements after the crystallization. Considering the high HFSE concentrations, it is more possible that grorudites have originated due to the primary magmatic differentiation. Processes of hydrothermal alteration did not affect significantly the studied rocks and resulted mainly in the partial replacement of the primary accessory minerals. We assume that crystallization of large bodies or intrusions of grorudites (agpaitic alkaline granites) took place at more fluid-saturated conditions, which facilitated prolonged melt differentiation; the influence of post-magmatic fluids on the concentration and migration of HFSE was more significant. Hence, large volumes of HFSE could have concentrated in such bodies of holocrystalline alkaline granites during the melt crystallization 
with subsequent separation of the volatile-enriched fluids. This process could promote the more effective redistribution and accumulation of HFSE minerals in the apical parts or contact zones of the intrusions.

Magmatic processes. The importance of magmatic processes for the HFSE enrichment and subsequent formation of the economical deposits follows from the melt inclusions studies. Unfortunately, such studies are not carried out for grorudites of the Azov region. Studies from other complexes, however, indicate that HFSE concentration in alkaline felsic magmas is higher than in other types of felsic melts and in some cases can reach the percentage level. For example, $\mathrm{Zr}, \mathrm{Nb}$ and REE concentrations reach $2.7,0.6$ and 0.3 wt \% correspondingly in melt inclusions in agpaitic granite of the Khaldzan-Buregtey massif [25]. Similar concentrations of these metals are recorded in melt inclusions in agpaitic granites of the Amis complex [42]. According to experimental studies, the solubility of $\mathrm{Zr}$ in metaluminous and plumasite granitic melts is below $100 \mathrm{ppm}[23,46]$, whereas in agpaitic melts it often exceeds 1 wt $\%$ [24, 31]. Moreover, the increased agpaitic index of the melt, and high alkali and fluorine concentrations facilitate solubility of HFSE due to the formation of alkaline-silicate and/or alkaline-fluoride compounds and increased proportion of non-bridging oxygen (comparing to metaluminous and peraluminous melts) that allows to increase concentration of HFSE [17, 19, 40, 46]. Therefore, the residual aluminosilicate melts from the crystallization differentiation of the primary magmas are enriched in $\mathrm{Nb}$, Ta and probably $\mathrm{Zr}$, Y and REE. Expectedly, their subsequent crystallization (after expelling of fluid phase) is accompanied by a rich gangue mineralization. Experimental data regarding $\mathrm{Nb}$ and Ta partition between aqueous F-fluids and aluminosilicate melt at high temperature $\left(900-1200{ }^{\circ} \mathrm{C}\right)$ [17] indicates that these elements are partitioned mainly into the alkaline aluminosilicate melt. Similar results regarding $\mathrm{Ta}$ and $\mathrm{Nb}$ partition between peralkaline granitic melt and F-alkaline fluids were obtained by [22]. Therefore, considering increased or high $\mathrm{Nb}$ concentrations in grorudites, the PT-conditions of differentiation (e. g., low $\mathrm{F}$ concentration, high $f \mathrm{O}_{2}$ and short crystallization term) probably did not facilitate appearance and subsequent accumulation of $\mathrm{Nb}$ minerals. Taking into account these data, as well as 1) the very low \# Mg and high agpaitic index of grorudites, 2) the increased concentration of
HFSE and REE, but low Sr and Ba, and 3) the moderate $\mathrm{Eu}^{*}(0.46-0.77)$ anomalies, accumulation of trace elements as a consequence of their concentration in the residual fractions of differentiated mafic and alkaline-mafic initial melts is most likely.

Conclusions. 1. The mafic minerals of high-Ti (aegirine-bearing) grorudites of the Azov region, especially amphiboles, appear to be more diverse in chemical composition than previously thought. During the early stage of their evolution the phenocrysts of $\mathrm{Ca}-\mathrm{Na}$ - and alkali amphiboles crystallized first. With increasing alkalinity and oxygen fugacity aegirine became more stable during the evolution.

2. The aegirine grorudite are more enriched in incompatible elements and consequently contains more abundant gangue mineralization compared with the amphibole type. In polished section significant part of rare-metal mineralization is spatially related to the titaniferous hematite, the main ore mineral of the aegirine-type grorudites. Probably, the close association of these minerals is a consequence of HFSE and REEs concentration in the residual iron-enriched melt phase. The latter could be formed as a result of liquid immiscibility between alkali silicate and Ti-Fe-rich melt at high alkalinity and volatile-rich fluids, which contribute to the partitioning of HFSE and REEs into the Ti-Fe-rich melt.

3. Taking into account the revealed peculiarities of gangue mineralization and some geochemical features of grorudites, these rocks crystallized without significant influence of hydrothermal alteration. The latter is observed only as partial replacement of primary accessory $\mathrm{Na}-\mathrm{Ca}-\mathrm{Zr}$-silicates and the appearance of secondary fluorocarbonates.

4. Considering their Devonian age, grorudites' mineralogical composition and incompatible element concentration indicate that these rocks belong to A-type granites, which are genetically related to primary subalkaline basaltic magmas similar to initial melts of the Pokrovo-Kyriyivo complex and other gabbro-syenitic massifs of the Eastern Azov region.

5. Further mineralogical and geochemical studies of grorudites of the Eastern Azov region are related not only with petrological and mineralogical importance but have also significant practical implications. Small intrusions of alkaline granites (holocrystalline analogues of grorudites, i. e. pantellerites and commendites), that potentially 
can be discovered in this region, may host occurrences or deposits of $\mathrm{Nb}, \mathrm{REE}, \mathrm{Zr}$, Sn, and $\mathrm{Be}$, like the Perga granites (Ukrainian Shield) or the Katugino deposit (Aldan Shield, Russia). Small massifs or intrusions of alkaline granites in the
Eastern Azov region could easily be missed during geological mapping or prospecting, because coarsegrained grorudites in the central parts of some dikes (for example Talova ravine) are macroscopically almost indistinguishable from the host granites.

\section{REFERENCES}

1. Aleksandrov, I.V. (1973), Models of Endogenic Tantalum-Niobium Ore Mineralization, Nauka, Moscow, RU, 148 p. [in Russian].

2. Amashukeli, Yu.A., Dubyna, O.V. and Kryvdik, S.G. (2011), Mineral. Journ. (Ukraine), Vol. 33, No. 4, Kyiv, UA, pp. 5365 [in Ukrainian].

3. Andreev, G.V. and Ripp, G.S. (1996), Zap. Vseros. mineral. ob-va, Ch. 125, Vyp. 6, Leningrad, RU, pp. $24-30$ [in Russian].

4. Andreev, G.V., Ripp, G.S., Sharakshinov, A.O. and Minin, A.D. (1994), Redkometalnaya mineralizatsiia shchelochnykh hranitoidov Zapadnoy Monholii, Izd-vo Buriat. nauch. tsentra, Ulan-Udé, RU, 137 p. [in Russian].

5. Buturlinov, N.V. (1979), Magmatism of graben-like depressions in the south of the East European Platform in Phanerozoic, Abstr. Thesis for Full Doctor in geol.-mineral. sci., Kyiv, 52 p. [in Russian].

6. Gorzhevskaya, S.A., Sidorenko, H.A. and Ginzburg, A.I. (1974), Titano-tantalo-niobaty, Nedra, Moscow, RU, 344 p. [in Russian].

7. Dubyna, O.V. and Kryvdik, S.G. (2013), Visnyk Kyiv Taras Shevchenko Nat. Univ., No. 1, Kyiv, UA, pp. 8-11 [in Ukrainian].

8. Eliseev, N.A., Kunshev, V.G. and Vinogradov, D.P. (1965), Proterozoic intrusive complex of Eastern Azov, Nauka, MoscowLeningrad, RU, 204 p. [in Russian].

9. Kvasnytsya, V.M., Vyshnevskyi, O.A., Kvasnytsya, I.V. and Gurnenko, I.O. (2016), Mineral. Journ. (Ukraine), Vol. 38, No. 3, Kyiv, UA, pp. 9-23 [in Ukrainian]. https://doi.org/10.15407/mineraljournal.38.03.009

10. Kryvdik, S.G., Voznyak, D.K., Sharygin, V.V. and Dubyna, O.V. (2012), Zap. Ukr. mineral. tov., Vol. 9, Kyiv, UA, pp. 7-34 [in Ukrainian].

11. Kryvdik, S.G. and Tkachuk, V.I. (1990), Petrologiya shchelochnyh porod Ukrainskogo shchita, Nauk. dumka, Kyiv, UA, 408 p. [in Russian].

12. Kryvdik, S.G. and Tkachuk, V.I. (1996), Mineral. Journ. (Ukraine), Vol. 18, No. 3, Kyiv, UA, pp. 67-83 [in Ukrainian].

13. Kryvdik, S.G., Sharygin, V.V., Gatsenko, V.O. and Lunev, E.S. (2016), Mineral. zb., No. 66, Vyp. 2, Lviv, UA, pp. $43-53$ [in Ukrainian].

14. Shatalov, N.N. (1986), Daiyky Pryazoviya, Nauk. dumka, Kyiv, UA, 190 p. [in Russian].

15. Ballouard, C., Poujol, M., Boulvais, P., Branquet, Y., Tartèse, R. and Vgneresse, J.-L. (2016), Geology, Vol. 44, pp. 231234.

16. Caroft, M., Maury, R.C., Leterrier, J., Joron, J.L., Cotton, J. and Guille, G. (1993), Lithos, Vol. 30, pp. 1-22.

17. Chevychelov, V.Y., Zaraisky, G.P., Borisovskii, S.E. and Borkov, D.A. (2005), Petrology, Vol. 13, pp. $305-321$.

18. Collerson, K.D. (1982), Contribs Mineral. and Petrol., Vol. 81, pp. 126-147.

19. Collins, W.J., Beams, S.D., White, A.J.R. and Chappell, B.W. (1982), Contribs Mineral. and Petrol., Vol. 80, pp. 189200.

20. Eby, G.N. (1992), Geology, Vol. 20, pp. 641-644.

21. Goodenough, K.M., Upton, B.G.J. and Ellam, R.M. (2000), Lithos, Vol. 51, pp. 205-221.

22. Gramenitskii, E.N. and Shchekina, T.I. (2001), Geochem. Int., Vol. 39, pp. 563-576.

23. Hanchar, J.M. and Watson, E.B. (2003), Zircon saturation thermometry, in Hanchar, J.M., Hoskin, P.W.O. Zircon, Reviews in Mineralogy and Geochemistry, Vol. 53, pp. 89-112.

24. Kogarko, L.N. (1990), Lithos, Vol. 26, pp. 167-175.

25. Kovalenko, V.I., Tsiaryeva, G.M., Goreglyad, A.V., Yarmolyuk, V.V. and Troitsky V.A. (1995), Econom. Geol., Vol. 90 , pp. 530-547.

26. Kramm, U. and Kogarko, L.N. (1994), Lithos, Vol. 32, pp. 225-242.

27. Kwak, T. and Abeysinghe, P.B. (1987), Mineral. Mag., Vol. 51, pp. 665-670.

28. Lester, G.W., Kyser, T.K., Clark, A.H. and Layton-Matthews, D. (2013), Chemical Geology, Vol. 357, pp. 178-185.

29. Markl, G., Marks, M., Schwinn, G. and Sommer, H. (2001), J. Petrology, Vol. 42, pp. 2231-2258.

30. Marks, M., Vennemann, T., Siebeland, W. and Mark, L.G. (2003), J. Petrology, Vol. 44, pp. 1247-1280.

31. Marr, R.A., Baker, D.R. and Williains-Jones, A.E. (1998), Canad. Mineral., Vol. 36, pp. 1001-1008.

32. Miller, R.R. (1986), Geology of the Strange Lake Alkalic Complex and the associated Zr-Y-Be-REE mineralizalion. Newfoundland Departmen of Mines and Energy, Mineral Development Division, Report 86-1. 1986, pp. 11-19.

33. Miller, R.R. (1990), The Slrange Lake pegmatile-aplite hosted rare metal deposit, Labrador: Newfoundland Department of Mines and Energy. Geological Survey Branch, Report 90-1, 1990, pp. 171-182.

34. Ryerson, F.J. and Hess, P.C. (1978), Geochim. et Cosmochim. acta, Vol. 42, pp. 921-932.

35. Salvi, S., Fontan, F., Monchoux, P., Williams-Jones, A.E. and Moine, B. (2000), Econom. Geol., Vol. 95, pp. 559-576.

36. Salvi, S. and Williams-Jones, A.E. (1990), Geochim. et Cosmochim. acta, Vol. 54, pp. 2403-2418. 
37. Salvi, S. and Williams-Jones, A.E. (1996), Geochim. et Cosmochim. acta, Vol. 60, pp. 1917-1932. https://doi. org/10.1016/0016-7037(96)00071-3

38. Salvi, S. and Williams-Jones, A.E. (2005), Alkaline granite-syenite deposits, in Linnen R.L., Samson I., Breaks F.W. Rare-element geochemistry and mineral deposits. Geological Association of Canada, 2005.

39. Scalliet, B. and MacDonald, R. (2001), J. Petrology, Vol. 42, pp. 825-845.

40. Scarfe, C.M. (1977), Canad. Mineral., Vol. 15, pp. 185-189.

41. Schmitt, A.K., Emmermann, L.R., Trumbull, R.B., Bühn, B., Henjes and Kunst. F. (2000), J. Petrology, Vol. 41, pp. 559-576.

42. Schmitt, A.K., Trumbull, R.B., Dulski, P. and Emmermann, R. (2002), Econom. Geol., Vol. 97, pp. 399-413.

43. Suk, N.I. (2012), Petrology, Vol. 20, No. 2, pp. 138-146.

44. Sun, S.-S. and McDonough, W.F. (1989), Geol. Society, Vol. 42, pp. 313-345.

45. Watson, E.B. (1976), Contribs Mineral. and Petrol., Vol. 56, pp. 119-134.

46. Watson, E.B. (1979), Contribs Mineral. and Petrol., Vol. 70, pp. 407-419.

47. Zajac, J.S. (1992), The Strange Lake Complex and its yttrium and zirconium mineralization. Society for Mining Metallurgy and Exploration Abstract, 1992, p. 69.

48. Zaraisky, G.P., Korzhinskaya, V. and Kotova, N. (2010), Mineral. and Petrol., Vol. 99, pp. 287-300. https://doi: 10.1007/ s00710-010-0112-z

Received 27.09.2019

\section{ЛІТЕРАТУРА}

1. Александров И.В. Модели эндогенного тантало-ниобиевого оруденения. М.: Наука, 1973. 148 с.

2. Амашукелі Ю.А., Дубина О.В., Кривдік С.Г. Деякі петрологічні та геохімічні критерії еволюції Октябрського масиву лужних порід (Україна). Мінерал. журн. 2011. 33, № 4. С. 53-65.

3. Андреев Г.В., Punn Г.С. Редкометальные эпидот-кварцевые метасоматиты массива Халдзан-Бурэгтэг. Зап. Всерос. минерал. об-ва. 1996. Ч. СХХV, № 6. С. 24-30.

4. Андреев Г.В., Рипn Г.С., Шаракшинов А.О., Минин А.Д. Редкометальная минерализация щелочных гранитоидов Западной Монголии. Улан-Удэ: Изд-во Бурятск. науч. центра, 1994. 137 с.

5. Бутурлинов Н.В. Магматизм грабенообразных прогибов юга Восточно-Европейской платформы в фанерозое: автореф. дис. ... д-ра геол.-мин. наук. Киев, 1979. 52 с.

6. Горжевская С.А., Сидоренко Г.А., Гинзбург А.И. Титано-тантало-ниобаты. М.: Недра, 1974. 344 с.

7. Дубина О.В., Кривдік С.Г. Геохімія грорудитів Східного Приазов’я. Вісн. КНУ ім. Т. Шевченка. 2013. № 1. C. $8-11$.

8. Елисеев Н.А., Кушев В.Г., Виноградов Д.П. Протерозойский интрузивный комплекс Восточного Приазовья. М.-Л.: Наука, 1965. 204 с.

9. Квасниия В.М., Вишневський О.А., Квасниия І.В., Гурненко І.В. Дипірамідальні кристали циркону із лужних порід Приазов’я. Мінерал. журн. 2016. 38, № 3. С. 9-23. doi: https://doi.org/10.15407/mineraljournal.38.03.009

10. Кривдік С.Г., Возняк Д.К., Шаригін В.В., Дубина О.В. Мінерали лужних порід України. Зап. Укр. мінерал. т-ва. 2012. 9. C. 7-34.

11. Кривдик С.Г., Ткачук В.И. Петрология щелочных пород Украинского щита. Киев: Наук. думка, 1990. 408 с.

12. Кривдік С.Г., Ткачук В.І. Грорудити Східного Приазов'я. Минерал. журн. 1996. 18, № 3. С. 67-83.

13. Кривдік С.Г., Шаригін В.В., Гаценко В.О., Луньов С.С. Високомангановий і високотитанистий магнетит із маліньїтів Покрово-Киріївського масиву (Приазов’я, Україна). Мінерал. зб. 2016. № 66, вип. 2. С. 43-53.

14. Шаталов Н.Н. Дайки Приазовья. Киев: Наук. думка, 1986. 190 с.

15. Ballouard C., Poujol M., Boulvais P., Branquet Y., Tartèse R., Vigneresse J.-L. Nb-Ta fractionation in peraluminous granites: A marker of the magmatic-hydrothermal transition. Geology. 2016, 44, P. 231-234.

16. Caroft M., Maury R.C., Leterrier J., Joron J.L., Cotten J., Guille G. Trace element behavior in the alkali basalt-comenditic trachyte series from Mururoa Atoll, French Polynesia. Lithos. 1993. 30, P. 1-22.

17. Chevychelov V.Y., Zaraisky G.P., Borisovskii, S.E., Borkov D.A. Effect of melt composition and temperature on the partitioning of $\mathrm{Ta}, \mathrm{Nb}, \mathrm{Mn}$, and $\mathrm{F}$ between granitic (alkaline) melt and fluorine-bearing aqueous fluid: Fractionation of $\mathrm{Ta}$ and $\mathrm{Nb}$ and conditions of ore formation in rare-metal granites. Petrology. 2005. 13. P. 305-321.

18. Collerson K.D. Geochemistry and Rb-Sr geochronology of associated proterozoic peralkaline and subalkaline anorogenic granites from Labrador. Contribs Mineral. and Petrol. 1982. 81. P. 126-147.

19. Collins W.J., Beams S.D., White A.J.R., Chappell B.W. Nature and origin of A-type granites with particular reference to southeast Australia. Contribs Mineral. and Petrol. 1982. 80. P. 189-200.

20. Eby G.N. Chemical subdivision of the A-type granitoids: petrogenetic and tectonic implications. Geology. 1992.20. P. 641-644.

21. Goodenough K.M., Upton B.G.J., Ellam R.M. Geochemical evolution of the Ivigtut Granite, South Greenland: a fluorinerich "A-type" intrusion. Lithos. 2000. 51. P. 205-221.

22. Gramenitskii E.N., Shchekina T.I. On the Geochemistry of Ta, Nb, Zr, and $\mathrm{Hf}$ in F-Enriched Granites and Alkaline Rocks: Experimental Data. Geochem. Int. 2001. 39. P. 563-576. 
23. Hanchar J.M., Watson E.B. Zircon saturation thermometry: in Hanchar J.M., Hoskin P.W.O. Zircon, Reviews in Mineralogy and Geochemistry. 2003. 53. P. 89-112.

24. Kogarko L.N. Ore-forming potential of alkaline magmas. Lithos. 1990. 26. P. 167-175.

25. Kovalenko V.I., Tsaryeva G.M., Goreglyad A.V., Yarmolyuk V.V., Troitsky V.A. The peralkaline granite-related KhaldsanBuregtey rare metal (Zr, Nb, REE) deposit Western Mongolia. Econom. Geol. 1995. 90. P. 530-547.

26. Kramm U., Kogarko L.N. Nd and Sr isotope signatures of the Khibina and Lovozero agpaitic centres, Kola Province, Russia. Lithos. 1994. 32, P. 225-242.

27. Kwak T., Abeysinghe P.B. Rare earth and uranium minerals present as daughter crystals in fluid inclusions, Mary Kathleen U-REE skarn, Queensland, Australia. Mineral. Mag. 1987. 51. P. 665-670.

28. Lester G.W., Kyser T.K., Clark A.H., Layton-Matthews D. Trace element partitioning between immiscible silicate melts with $\mathrm{H}_{2} \mathrm{O}, \mathrm{P}, \mathrm{S}, \mathrm{F}$, and Cl. Chemical Geology. 2013. 357. P. 178-185.

29. Markl G., Marks M., Schwinn G., Sommer H. Phase equilibrium constraints on intensive crystallization parameters of the Illimaussaq Complex, South Greenland. J. Petrology. 2001. 42. P. 2231-2258.

30. Marks M., Vennemann T., Siebel W., Mark L.G. Quantification of magmatic and hydrothermal processes in a peralkaline syenite-alkali granite complex based on textures, phase equilibria, and stable and radiogenic isotopes. J. Petrology. 2003. 44. P. $1247-1280$.

31. Marr R.A., Baker D.R., Williains-Jones A.E. Chemical controls on the solubility of Zr-bearing phases in simplified peralkaline melts and application to the Strange Lake intrusion, Quebec-Labrador. Canad. Mineral. 1998. 36. P. 10011008.

32. Miller R.R. Geology of the Strange Lake alkaline complex and the associated Zr-Y-Be-REE mineralizalion. Newfoundland Departmen of Mines and Energy, Mineral Development Division, Report 86-1. 1986. P. 11-19.

33. Miller R.R. The Slrange Lake pegmatile-aplite hosted rare metal deposit, Labrador: Newfoundland Department of Mines and Energy. Geological Survey Branch, Report 90-1. 1990. P. 171-182.

34. Ryerson F.J., Hess P.C. Implications of liquid-liquid distribution coefficients to mineral-liquid partitioning. Geochim. et cosmochim. acta. 1978. 42. P. 921-932.

35. Salvi S., Fontan F., Monchoux P., Williams-Jones A.E., Moine B. Hydrothermal mobilization of HFSE in alkaline igneous systems: evidence from the Tamazeght Complex (Morocco). Econom. Geol. 2000. 95. P. 559-576.

36. Salvi S., Williams-Jones A.E. The role of hydrothermal processes in the granite hosted Zr, Y, REE deposit at Strange Lake, Quebec/Labrador: evidence from fluid inclusions. Geochim. et cosmochim. acta. 1990. 54. P. 2403-2418.

37. Salvi S., Williams-Jones A.E. The role of hydrothermal processes in concentrating HFSE in the Strange Lake peralkaline complex, northeastern Canada. Geochim. et cosmochim. acta. 1996. 60. P. 1917-1932.

38. Salvi S., Williams-Jones A.E. Alkaline granite-syenite deposits. In Linnen R.L., Samson I., Breaks F.W. Rare-element geochemistry and mineral deposits. Geological Association of Canada. 2005.

39. Scalliet B., MacDonald R. Phase relations of peralkaline silicic magmas and petrogenetic implications. J. Petrology. 2001. 42. P. 825-845.

40. Scarfe C.M. Viscosity of a pantellerite melt at one atmosphere. Canad. Mineral. 1977. 15. P. 185-189.

41. Schmitt A.K., Emmermann L.R., Trumbull R.B., Bühn B., Henjes Kunst. F. Petrogenesis and ${ }^{40} \mathrm{Ar} /{ }^{30} \mathrm{Ar}$ geochronology of the Brandberg Complex, Namibia: evidence of major mantle contribution in mantle and peralkatine granites. J. Petrology. 2000. 41. P. 559-576.

42. Schmitt A.K., Trumbull R.B., Dulski P., Emmermann R. Zr-Nb-REE mineralization in peralkalinc granites from the Amis Complex. Brandberg (Namibia): evidence for magmatic pre-enrichment from melt inclusions. Econom. Geol. 2002. 97. P. 399-413.

43. Suk N.I. Experimental study of liquid immiscibility in the fluid-magmatic silicate systems containing Ti, Nb, Sr, REE, and Zr. Petrology. 2012. 20, № 2. P. 138-146.

44. Sun S.-S., McDonough W.F. Chemical and isotopic systematic of oceanic basalts: implications for mantle composition and processes. Geological Society. 1989. 42. P. 313-345.

45. Watson E.B. Two-liquid partition coefficients: experimental data and geochemical implications. Contribs Mineral. and Petrol. 1976. 56. P. 119-134.

46. Watson E.B. Zircon saturation in felsic liquids: Experimental results and applications to trace element geoschemistry. Contribs Mineral. and Petrol. 1979. 70. P. 407-419.

47. Zajac J.S. The Strange Lake complex and its yttrium and zirconium mineralization. Society for Mining Metallurgy and Exploration Abstract, 1992. P. 69.

48. Zaraisky G.P., Korzhinskaya V., Kotova $N$. Experimental studies of $\mathrm{Ta}_{2} \mathrm{O}_{5}$ and columbite-tantalite solubility in fluoride solutions from 300 to $550{ }^{\circ} \mathrm{C}$ and 50 to 100 MPa. Mineral. and Petrol. 2010. 99. P. 287-300. https://doi:10.1007/s00710010-0112-Z

Надійшла 27.09.2019 
O.В. Дубина, д-р геол. наук, доц. пров. наук. співроб. Інститут геохімії, мінералогії та рудоутворення ім. М.П. Семененка НАН України

03142, Київ, Україна, пр-т Акад. Палладіна, 34

Київський національний університет імені Тараса Шевченка

Навчально-науковий інститут "Інститут геології"

03022, Київ, Україна, вул. Васильківська, 90

E-mail: dubyna_a@ukr.net

http://orcid.org/0000-0002-6003-4873

С.Г. Кривдік, д-р геол.-мін. наук, проф., зав. від. Інститут геохімії,

мінералогії та рудоутворення ім. М.П. Семененка НАН України

03142, Київ, Україна, пр-т Акад. Палладіна, 34

E-mail: kryvdik@ukr.net

http://orcid.org/0000-0002-8356-1115

O.A. Вишневський, канд. геол.-мін. наук, пров. наук. співроб. Інститут геохімії, мінералогії та рудоутворення ім. М.П. Семененка НАН України

03142, Київ, Україна, пр-т Акад. Палладіна, 34

E-mail: vyshnevskyy@i.ua

Researcher ID: I-9996-2018

\section{МІНЕРАЛОГО-ПЕТРОЛОГІЧНІ ОСОБЛИВОСТІ ГРОРУДИТІВ СХІДНОГО ПРИАЗОВ'Я (УКРАЇНА)}

У межах Українського щита лужні граніти та їхні гіпабісальні й ефузивні аналоги поширені обмежено. У Східному Приазов'ї відомі дайкові аналоги лужних гранітів (грорудити), які є дискретними за хімічним та мінеральним складом і розглядаються як аналоги пантелеритів (егіринові високотитанисті) або комендитів (амфіболові низькотитанисті). Високотитанисті егіринові грорудити інтенсивніше збагачені некогерентними рідкісними елементами (REE, $\mathrm{Zr}, \mathrm{Nb})$ порівняно з низькотитанистими різновидами. У результаті останніх досліджень виявлено нові для цих порід мінерали титану (титанистий гематит із підвищеним вмістом МnO, різновиди серії $\mathrm{FeTiO}_{3}-\mathrm{MnTiO}_{3}-\mathrm{ZnTiO}_{3}$ ), невідомі раніше в цих породах $\mathrm{Ca}-\mathrm{Na}-$ амфіболи, а також структурні взаємовідношення егірину та лужного амфіболу. Незважаючи на високий або підвищений вміст HFSE в грорудитах, інформації про власні мінерали-концентратори цих елементів майже не було. В егіринових різновидах нами виявлено і проаналізовано мінерали рідкісних елементів - монацит-(Се), бастнезит-(Се), бритолітоподібний мінерал та рідкісноземельний апатит, циркон, Ca-Na-катаплеїт, а також остаточно недіагностовані мінерали цирконію та мінерал групи ешиніту. В амфіболовому грорудиті із акцесорних мінералів виявлено лише циркон і ніобійвмісний рутил. Згадані мінерали часто мають дуже дрібні розміри, найбільші з них можуть досягати $15-20 \mu \mathrm{m}$, більшість не перевищує $10 \mu \mathrm{m}$, що значно ускладнює їх остаточну діагностику. Цікавим і досить незвичним виявилося те, що значна частина рідкісних мінералів, особливо бастнезит- $(\mathrm{Ce})$, мінерал типу ешиніту, циркон, утворюють включення у більших зернах титанистого гематиту. Припускається, що значна частина рідкісних металів може ізоморфно входити до складу породоутворювальних мінералів (лужних піроксенів та амфіболів), а циркон та інші недіагностовані мінерали $\mathrm{Zr}$ (принаймні їхня частина) є вторинними і утворилися за рахунок первинних натрієвих (евдіаліт, катаплеїт, ілерит) або кальцієвих (гітинсит, кальціокатаплеїт) цирконосилікатів, характерних для перенасичених лугами (агпаїтових) порід. Зважаючи на петрологічні особливості та характер рідкісноземельної мінералізації грорудитів Приазов'я, є підстави вважати, що рідкіснометалева мінералізація в цих породах $є$ наслідком диференціації вихідних магматичних розплавів, які за складом подібні до титанистих базальтів (характерних порід цього району). Вторинні гідротермальні процеси слабко проявлялися у досліджуваних породах і призводять переважно до замішення первинних акцесорних мінералів. Ураховуючи підвищену або високу концентрацію $\mathrm{Nb}$ у високотитанистих грорудитах і незначну кількість $\mathrm{Nb}$-мінералів, ймовірно, що фізико-хімічні параметри диференціації магматичних розплавів (низька концентрація $\mathrm{F}$, висока $f \mathrm{O}_{2}$ і гіпабісальні умови формування) не сприяли повній розкристалізації та накопиченню рідкіснометалевої мінералізації. Проте наявність грорудитів із високим вмістом рідкісних металів у цьому регіоні вказує на перспективи виявлення невеликих масивів подібних лужних гранітів (розкристалізованих аналогів грорудитів), з якими можуть бути пов'язані родовища та/або прояви $\mathrm{Nb}, R E E, \mathrm{Zr}, \mathrm{Sn}, \mathrm{Be}$.

Ключові слова: грорудит, лужний граніт, ешиніт-(Се), цирконієві мінерали, монацит-(Се), бастнезит-(Се), бритолітоподібний мінерал, $R E E$-апатит, Na-збагачений кальціокатаплеїт. 